\title{
Okul Öncesi Öğretmenlerinin Sınıflarındaki Gelişimsel Yetersizliği Olan ve Olmayan Çocuklarla Etkileşim Davranışlarının İncelenmesi*
}

\section{Semra OMAK ${ }^{* *}, \quad$ Elif SAZAK ${ }^{* * *}$}

Öz: Bu çalışmanın amacı okul öncesi öğretmenlerinin gelişimsel yetersizliği olan ve olmayan çocuklarla etkileşim davranışlarının incelenmesidir. Çalışmada öğretmenlerin etkileşim davranışlarının sıklığı ve etkileşim davranışları sıklığının gelişimsel yetersizliği olup olmama durumuna göre farklılaşıp farklılaşmadığı araştırılmıştır. Çalışmaya Ankara'nın Altındağ ve Çubuk ilçesinde Milli Eğitim Bakanlığı'na bağlı bağımsız anaokulları ve anasınıflarında bulunan 14 okul öncesi öğretmeni ve gelişimsel yetersizliği olan ve olmayan 32 çocuk katılmıştır. Araştırma nicel araştırma deseninin kullanıldığı betimsel bir çalışmadır. Araştırma verilerini toplamada gözlem tekniği kullanılmıştır. Öğretmenlerin etkileşim davranışlarına ilişkin veriler araştırmacılar tarafından geliştirilen “Öğretmen Etkileşim Davranışları Gözlem Formu” ve "Öğretmen ve Öğrenci Bilgi Formu" ile elde edilmiştir. Çalışmanın sonucunda öğretmenlerin gelişimsel yetersizliği olan ve olmayan çocuklarla genel etkileşim davranışlarında anlamlı bir farklılık ortaya çıkmazken, bu davranışların bazı alt boyutlarında (çocuğa sözel ya da sözel olmayan uyaran sunma, çocukla fiziksel etkileşim kurma, çocuğa gereksinim duyduğunda yardım etme ve çocuğu etkinliğe doğru yeniden yöneltme/yönlendirme) gelişimsel yetersizliği olup olmama durumuna göre anlamlı bir fark bulunmuştur. Öğretmenlerin gelişimsel yetersizliği olan çocuklarla daha s1k etkileşim davranışlarını sergiledikleri görülmüştür.

Anahtar Kelimeler: Öğretmen etkileşim davranışları, gelişimsel yetersizlik, okul öncesi dönem, okul öncesi öğretmenleri, kaynaştırma.

\footnotetext{
*Bu çalışma Abant İzzet Baysal Üniversitesi Eğitim Bilimleri Enstitüsü’nde Doç. Dr. Elif Sazak danışmanlığında yürütülen Semra Omak'ın yüksek lisans tezi kapsamında yapılmıştır ve 28 Eylül - 1 Ekim 2017 tarihlerinde 2. Uluslararası Çağdaş Eğitim Araştırmaları Kongresi'nde sözlü bildiri olarak sunulmuştur.

**Araş. Gör. Ahi Evran Üniversitesi, Eğitim Fakültesi, Zihin Engellilerin Eğitimi Anabilim Dalı, email: semra.omak12@hotmail.com Orcid No: https://orcid.org/0000-0002-2367-9736

***Doç. Dr. Abant İzzet Baysal Üniversitesi, Eğitim Fakültesi, Zihin Engellilerin Eğitimi Anabilim Dalı, email: elifsazak@hotmail.com Orcid No: https://orcid.org/0000-0003-3530-9588

**** $\mathrm{Bu}$ araştırma için Abant İzzet Baysal Üniversitesi Sosyal Bilimlerde İnsan Araştırmaları Etik Kurulu Başkanlığında (17.05.2016 tarihli ve 2016/03) etik izin alınmıştır.
} 


\section{Investigation of Pre-School Teachers' Interaction Behaviors with Developmentally Disabled and Non-Disabled Children in Their Classrooms \\ Views}

Abstract: The aim of this work is to investigate pre-school teachers' interaction behaviours with developmental disability and non-disabled children. In this work, frequency of interaction behaviours of teachers and whether the frequency of interaction behaviours of teachers varies according to the developmental adequacy or not was researched. This work includes 14 preschool teachers and 32 developmentally disabled and non-disabled children from independent pre-school affiliated to the Ministry of National Education which are located in Altındağ and Çubuk provinces of Ankara. The research is a descriptive study using quantitative research method. Research data consists from observation technique. "Teacher Interaction Behavior Observation Form" and "Teacher and Student Information Form” developed by researchers has been used to evaluate the teachers' interaction behaviors. As a result of this study, there was no significant difference found out in the general interaction behaviours of the teachers to the children with and without development disability but a significant difference was found in some sub-dimensions of these behaviours (teacher offers child verbal or non-verbal stimulus, establishes a physical interaction with the child, helps whenever the child needs, rechannels/guides child to the activity) according to the presence or absence of developmental disability. It is understood that teachers use interaction behaviours more frequently with children who are having development disabilities.

Keywords: Teacher-child interaction behaviors, developmental disability, pre-school teachers, pre-school education, mainstreaming.

\section{Giriș}

Erken çocukluk dönemi, çocukların gelişimlerinin her alanında temel becerileri kazandıkları yılları kapsamaktadır (Acarlar, 2013). Bu dönemdeki erken öğrenmelerin çocukların bilişsel, sosyal, duygusal, dil gelişimlerini ve ilerleyen yıllardaki başarılarını etkilediği vurgulanmaktadır (Barnett, 1995; Bradley, 1998). Erken çocukluk dönemi çocuğun yaşamı boyunca kullanacağı işlevsel yaşam becerilerinin temellerinin atıldığı dönemdir. $\mathrm{Bu}$ dönemde çocukları etkileyen faktörler onların tüm gelişim alanlarını farklı düzeyde 
etkilemektedir (Bertan, Haznedaroğlu, Koln, Yurdakök ve Güçiz, 2009). Erken çocukluk dönemini etkileyen en önemli faktörlerden biri de erken çocukluk eğitimidir.

Erken çocukluk eğitimi, doğumdan başlayarak ilköğretim yıllarına (0-6 yaş) kadar devam eden, çocuğun doğuştan getirdiği potansiyelini en üst düzeyde kullanmasına olanak sağlayan ortamı ailede, toplumda ve kurumlarda sağlamayı amaçlayan, çocuğun bilişsel, sosyal, dil ve motor becerilerini destekleyen bir süreçtir (Odom, Yoder ve Hill, 1988). Bu dönemde normal gelişim gösteren çocuklar kendilerine sağlanan öğrenme olanakları doğrultusunda temel bilgi ve becerileri kazanabilmektedirler. Tüm çocukların hayatında önemli bir yer oluşturan erken çocukluk eğitimi (Odluyurt, 2012), gelişimsel yetersizliği olan çocukların yeterince yararlanamadıkları bir eğitim sürecini oluşturmaktadır (Kırcaali İftar, 1992).

Gelişimsel yetersizliği olan çocuklar, alıcı ve ifade edici dil, öğrenme, kendi kendini yönetme, hareket yeteneği, öz bakım ve bağımsız yaşam becerileri gibi temel yaşam becerilerinin bir ya da birkaçında önemli ölçüde işlevsel sınırlılıklar yaşayan çocuklardır (State of Delaware Developmental Disabilities Council, 2007). Bu çocuklar çeşitli nedenlerle bireysel özellikleri ve eğitim yeterlilikleri açısından akranlarından beklenilen düzeyde anlamlı farklılıklar gösterdikleri (Milli Eğitim Bakanlığı [MEB], 1997) için çoğunlukla erken çocukluk eğitimden yararlanamamaktadırlar. Oysa erken çocukluk eğitimi gelişimsel yetersizliği olan çocuklara uyarıcı yönünden zengin çevre olanakları sağlamaktadır. Onların bedensel, zihinsel, sosyal, duygusal, dil ve iletişim becerilerini destekleyerek toplum içinde bir birey olarak rol almalarını ve yaşamlarının ilerleyen yıllarında bağımsız yaşam becerilerini kazanmalarını sağlamaktadır (Özbaba, 2000). Gelişimsel yetersizliği olan çocukların hayatında rastlantılara bırakılmayacak kadar önemli bir süreci ve eğitimin en can alıcı noktasını oluşturan erken çocukluk eğitiminin (Arı, 2005), sistemli ve planlı bir şekilde uyarlanıp yürütülmesi gerekmektedir (Avcı ve Ersoy, 2002).

Gelişimsel yetersizliği olan çocuklara erken çocukluk eğitimi çocuğun yaşına, yetersizlik türüne ve ailenin gereksinimlerine uygun olarak eve dayalı, eve ve kuruma dayalı ve kuruma dayalı programlar olmak üzere farklı şekillerde verilmektedir (Yıldırım Doğru, 2013). Aileyi temel alan eve dayalı erken çocukluk eğitimi programlarının amacı çocuğun iyi beslenmesi, sağlıklı olması ve tüm gelişim alanlarını desteklemeye yardımcı olacak ev ortamı yaratmak için anne-baba ve çocuğa bakan diğer kişilere eğitim vermektir (Erdoğan, 2010). Ev ziyaretleri ve kuruma dayalı etkinliklerden oluşan eve ve kuruma dayalı erken çocukluk eğitimi programlarının amacı, gelişimsel yetersizliği olan çocuğun ihtiyaçlarının belirlenmesi, sosyal yönden gelişimini desteklemek ve ailelerin eğitsel oyun, oyuncak vb. konularda bilgi ve 
deneyimlerini artırmaktır. Kuruma dayalı erken çocukluk eğitimi programları ise gelişimsel yetersizliği olan çocukların yaşına ve gelişim düzeyine uygun bir kurumda yürütülen programlardır (Yıldırım Doğru, 2013). Gelişimsel yetersizliği olan çocukların kuruma dayalı programlara uygun yararlandıkları en önemli erken çocukluk eğitimi şekli kaynaştırmadır.

Kaynaştırma gelişimsel yetersizliği olan çocukların gerekli destek hizmetler sağlanarak tam ya da yarı zamanlı olarak kendisi için en az kısıtlayıcı eğitim ortamı olan normal eğitim ortamlarında normal gelişim gösteren akranlarıyla birlikte eğitim görmesidir (Kırcaali İftar, 1992). Erken çocukluk eğitiminde kaynaştırma uygulamaları birçok uzman ve öğretmen tarafından gelişimsel yetersizliği olan çocuklar için en iyi uygulamalardan biri olarak görülmektedir (Henninger ve Gupta, 2014; Odom ve McEvoy, 1990). Bunun nedeni kaynaştırma uygulamaları yürütülen sınıfların gelişimsel yetersizliği olan çocukların öğretimden en iyi şekilde yararlanabilecekleri ve akranlarıyla en üst düzeyde birlikte olabilecekleri en az kısıtlayıcı çevre olmasıdır (File ve Kontos, 1992; Individuals with Disabilities Education Act [IDEA], 2004). Erken çocukluk döneminde kaynaştırma uygulamalarının başarısını etkileyen pek çok faktör bulunmaktadır. Bu faktörlerin başında öğretmen davranışları ve tutumları gelmektedir (Batu, 2010).

Erken çocukluk eğitiminde normal gelişim gösteren çocuklar gibi gelişimsel yetersizliği olan çocuklar da teşvik etme, dönüt verme, ödüllendirme, motive etme, yönlendirme, ipucu sunma, yanıt verme, destekleme ve öğrenme firsatı sunma gibi öğretmen davranışlarına ihtiyaç duymaktadırlar (Başar, 1998; Rakap ve Rakap Parlak, 2011). Gelişimsel yetersizliği olan çocuklar sınıf ortamında çoğu zaman verilen yönergeleri anlayamamakta ve becerileri sergilemekte zorlanmaktadırlar. Öğretmenler bu çocukların anlayamadığı durumlarda oldukça basit ve sade yönergeler vermeli ve yeniden yönlendirmelidirler. Eğer çocuklar belirtilen beceriyi gerçekleştiremiyorsa ipucu sunmalıdırlar. Çoğu zaman gelişimsel yetersizliği olan çocuklar sınıf ortamında ne yapacağını anlamakta zorlandıkları için daha fazla yardıma ihtiyaç duyabilirler. Öğretmenler bu durumda çocuğa beceriyi nasıl gerçekleştireceği konusunda model olmalı ve sözel ifadeler kullanmalıdırlar (Özen, 2010). Gelişimsel yetersizliği olan çocuklar etkinlikler sırasında öğretmenlerin bir beceriyi gerçekleştirdiğinde dönütler verebilmesine, bir gülümseme veya bir baş onayına ihtiyaç duyarlar. Öğretmenler etkinlik sırasında aralıklarla çocukları izlemeli, bir beceriyi gerçekleştiremediğinde yardım etmeli, beceriyi gerçekleştirdiğinde geri dönüt vermeli ve desteklemelidirler (Tüfekçioğlu, 2001). Gelişimsel yetersizliği olan çocukları bir birey olarak kabul edip onlara yönelik kabul edici ve destekleyici bir tutum sergileyen öğretmenler çocukların kendilerini ifade etmelerine, özgüvenlerinin 
artmasına olanak verebilir ve onlarda öğrenme isteği oluşturabilirler (Kargın, 1997). Öğretmenlerin olumlu tutumları bu çocukların öğrenmeden olumlu deneyimler elde etmelerini sağlayabilir (Wortham, 1998).

Erken çocukluk eğitiminde kaynaştırma uygulamalarının yapıldığı sınıflarda bazı öğretmenlerin gelişimsel yetersizliği olan çocuklara karşı olumsuz tutum içinde olduğu görülmektedir (Schulz, Carpenter ve Turnbull, 1991; Akt. Artan ve Uyanık Balat, 2003). Bu öğretmenlerin gelişimsel olarak desteklenmeye ihtiyaç duyan çocuğu fark edememeleri, gelişimsel ihtiyaçlarını tespit edememeleri, çocuğu cezalandırma, akranlarıyla kıyaslama gibi olumsuz tutum içinde olmaları çocuğun yaşamını olumsuz bir şekilde etkilemektedir (Johnston, 2010). Olumsuz tutumlar içinde olan öğretmenler gelişimsel yetersizliği olan çocukların gelişimsel ihtiyaçlarını tespit edemedikleri için uygun öğrenme ortamları hazırlayamayabilmektedirler. Buna bağlı olarak gelişimsel düzeylerine uygun öğrenme ortamlarından yararlanamayan çocukların bilişsel, sosyal, duygusal, dil ve iletişim becerilerindeki gelişimleri olumsuz etkilenebilmektedir.

Gelişimsel yetersizliği olan çocukların erken öğrenme deneyimlerini yaşadığı kaynaştırma sınıflarının başarısında öğretmen etkileşim davranışlarının önemli bir rolü vardır. Öğretmen etkileşim davranışları, öğretim süreci boyunca öğretim ortamlarında öğretmenlerin çocukları etkileme ve destekleme amacıyla gösterdiği sözel veya sözel olmayan davranışlardır. Alan yazında birçok araştırmada etkileşim davranışları duyarlı olma, yanıtlayıcı olma, kabullenme, yönlendirici olma, pekiştireç kullanma ve keyif alma (Hamre ve Pianta, 2005; Elicker ve Fortner Wood, 1995; Mahoney ve Powell, 1988; Mahoney ve Wheeden, 1999) olarak ele alınmıştır. $\mathrm{Bu}$ davranışlar öğrenmeleri destekleyerek eğitim ortamlarında gelişimsel yetersizliği olan çocukların sosyal, duygusal ve bilişsel kazanımlarına temel oluşturması bakımından önemlidir (Pianta, 1997; Şeker, 2000). Çocukların çevrelerini keşfetmesi ve güvenli bir ortamda olduğunu hissetmesinde öğretmen etkileşim davranışlarının büyük katkısı bulunmaktadır (Howes ve Smith, 1995). Bredekamp ve Copple'ın (1997) göre öğretmen etkileşim davranışları gelişimsel yetersizliği olan çocukları denemeye, yanlışlarını öğrenmeye, kendini düzenleme, karar verme, problem çözme ve soru sormaya teşvik eder (Akt. Tu ve Hsiao, 2008). Öğrencilerle duyarlı ve yanıtlayıcı etkileşimler kuran öğretmenler öğrencilerin gelişimini hızlandırırlar (Elicker ve Fortner Wood, 1995). Öğretmenlerin duyarlı ve yanıtlayıcı etkileşim davranışlarını kullandığı öğrencilerinin sosyal, dil becerileri daha çok gelişmiş ve bilişsel görevlerde daha yüksek düzeyde performans sergilediği görülmüştür (Howes, 1997). Öğretmenlerin davranışlarını yanıtlayıcı ve destekleyici olarak algılayan çocuklar okulu ve 
öğretmeni olumsuz algılayan çocuklara göre kendilerini daha güvende hissetmekte ve daha uyumlu tavırlar sergilemektedir (Murray ve Greenberg, 2000). Öğretmen etkileşim davranışları gelişimsel yetersizliği olan çocuklara olumlu öğrenmeler sağlayarak ilerleyen yaşamlarında birçok beceriyi kazanmaları için firsat sunmaktadır.

Erken çocukluk döneminde gelişimsel yetersizliği olan çocuklar öğretmenlerinin yönlendirmesine daha çok ihtiyaç duyabilirler. Öğretmenlerin bu dönemde gelişimsel yetersizliği olan çocuklarla etkileşiminin niteliğini artırması ve destekleyici olması çocukların gelişiminde çok önemlidir. Alan yazında öğretmenlerin öğrencileriyle olan etkileşimini inceleyen çalışmalarda öğretmenlerin gelişimsel yetersizliği olan öğrencilerle gelişimsel yetersizliği olmayan öğrencilere oranla daha olumsuz etkileşim kurduklarını (Nelson ve Roberts, 2000), öğretmen-öğrenci etkileşimlerinin çocukların özelliklerinden (utangaçlık, kendini kontrol etme, cinsiyet ve problem davranışlarından) etkilendiği (Hagekull ve Hammarberg, 2004; Roorda, Koomen, Spilt, Thijs ve Oort, 2013), çocukların kişilik özelliklerinin (utangaçlık, kendini kontrol etme ve cinsiyet) öğretmenin ve öğrencinin etkileşimi başlatma sıklığını etkilediği (Rudasill, 2011; Rudasill ve Kaufman, 2009) öğretmen özelliklerinin (bilgi ve deneyim) öğretmen-öğrenci etkileşiminin niteliğini belirlemede etkili olduğu (Trawick Smith ve Dziurgot, 2010), etkileşimlerde daha yanıtlayıcı davranışlar gösteren öğretmenlerin öğrencilerin bilişsel, sosyal, duygusal, dil ve iletişim becerilerinin gelişiminde ve öğrencilerin etkileşimi başlatmalarında etkili olduğu (Hamre, Hatfield, Pianta ve Jamil, 2014; Tseng, 2015) sonuçlarına ulaşılmıştır. Alan yazında öğretmenlerin gelişimsel yetersizliği olan ve olmayan çocuklar ile etkileşimlerini inceleyen araştırmalar bulunsa da Türkiye'de erken çocukluk döneminde kaynaştırma uygulamalarının yapıldığı sınıflarda öğretmen-öğrenci etkileşim davranışlarını inceleyen sadece bir çalışmaya (Demir, 2016) rastlanılmaktadır. $\mathrm{Bu}$ çalışmada öğretmenlerin gelişimsel yetersizliği veya risk grubu olan çocuklarla serbest zaman ve masa başı etkinlikleri sırasında etkileşim düzeyleri ve çocukların akranlarıyla etkileşim düzeyleri incelenmiştir. Araştırmanın sonucunda öğretmenlerin serbest zaman ve masa başı etkinlikleri sırasında çocuklarla benzer şekilde etkileşim kurduğu ve gelişimsel yetersizliği veya risk gurubunda olan çocukların ise serbest zaman etkinliklerinde masa başı etkinliğine oranla daha çok etkileşim kurduğu ortaya çıkmıştır. Fakat bu araştırmada öğretmenlerin etkileşim davranışlarının çocukların gelişimsel yetersizliği olup olmama durumlarına göre bir fark olup olmadığ incelenmemiştir. Erken çocukluk döneminde özellikle gelişimsel yetersizliği olan çocuklar normal gelişim gösteren çocuklara göre daha fazla etkileşime ihtiyaç duymaktadırlar. Bu dönemde anne-babanın yanı sıra bu çocuklarla en fazla etkileşime giren 
öğretmenleridir. $\mathrm{Bu}$ nedenle erken çocukluk döneminde öğretmenlerin çocuklarla olan etkileşim davranışları önemlidir. Erken çocukluk döneminde öğretmenlerin etkileşim davranışları çocukların bilişsel, sosyal, duygusal, dil ve iletişim becerilerinin gelişiminde etkilidir. Öğretmen etkileşim davranışları çocukların arkadaşlık kurma, oyuna katılma, iletişimi başlatma gibi girişimlerde bulunmasını sağlayarak çevresiyle etkileşimini kolaylaştırır ve günlük yaşam becerilerine katkı sağlayacak etkinliklerle çocuğun toplumun bir parçası olmasına katkı sağlar (Kırcaali İftar, 1998). Erken çocukluk döneminde öğretmenlerin etkileşim davranışlarının çocukların gelişimsel yetersizliği olup olmama durumlarına göre incelenmesi, öğretmenlerin çocuklarla etkileşimlerinin ve öğretimsel desteğinin niteliğinin belirlenmesi ve öğretmenlerin farkındalığını artırarak gelişimsel yetersizliği olan çocuklara karşı olumlu tutum geliştirmelerini sağlaması düşünülmektedir. $\mathrm{Bu}$ düşünceler doğrultusunda yapılan bu araştırmanın amacı erken çocukluk döneminde öğretmenlerin etkileşim davranışlarının çocukların gelişimsel yetersizliği olup olmama durumlarına göre incelenmesidir. Bu genel amaç doğrultusunda aşağıdaki sorulara yanıt aranmıştır:

1. Öğretmenlerin gelişimsel yetersizliği olan ve olmayan çocuklarla (büyük grup) masa başı ve oyun etkinlikleri sırasında etkileşim davranışlarının sıklığı nedir?

2. Masa başı etkinlikleri sırasında öğretmenlerin etkileşim davranışlarının sıklığında çocukların gelişimsel yetersizliği olup olmama durumlarına göre bir farklılık var midir?

3. Oyun etkinlikleri sırasında öğretmenlerin etkileşim davranışlarının sıklığında çocukların gelişimsel yetersizliği olup olmama durumlarına göre bir farklılık var mıdır?

\section{Yöntem}

$\mathrm{Bu}$ çalışma, nicel araştırma deseninin kullanıldığı betimsel bir araştırmadır. Nicel araştırma; deneme, gözlem ve deneylere dayanılarak yapılan görgül (amprik) araştırma yaklaşımına ya da gözlem ve ölçmelerin tekrarlanabildiği niceliksel veya sayısal araştırma yaklaşımına denmektedir (Ekiz, 2003). Bu araştırmada hem sayısal veriler ve bu verilere ait analiz yöntemlerinin kullanıldığı hem de nicel araştırma tekniklerinden gözlemden yararlanıldığ 1 için, nicel bir araştırmadır. Gözlem verilerin toplanmasında ise belirli sözel veya sözel olmayan davranışlardan oluşan yapılandırılmış gözlem formundan yararlanılmıştır. Yapılandırılmış gözlem formunda ortamda sergilenen davranışlar gözlenebilir ve ölçülebilir hale getirilmektedir (Yıldırım ve Şimşek, 2016). Bu çalışmada da anaokulu ve anasınıfında eğitim gören gelişimsel yetersizliği olan ve olmayan çocukların sözel ve sözel olmayan 
davranışları gözlenebilir ve ölçülebilir hale getirilmiş, ardından bu davranışlar hazırlanan gözlem formu ile yarı yapılandırılmış ortamda değerlendirilmiştir.

\section{Çalışma Grubu}

Araştırma Ankara'da bulunan Milli Eğitim Bakanlığı'na bağlı beş bağımsız anaokulu ve beş anasınıfında yürütülmüştür. Araştırmaya 12 okul öncesi öğretmenin sınıfından gelişim yetersizliği olan ve olmayan birer çocuk ile iki öğretmenin sınıfından gelişim yetersizliği olan ve olmayan ikişer çocuk olmak üzere toplam 14 öğretmen ve 32 çocuk katılmıştır. Katılımcı grubuna ilişkin bilgiler Tablo 1 ve Tablo 2' de verilmiştir.

Tablo 1. Katılımcı öğretmenlerin özellikleri

\begin{tabular}{llll}
\hline Değişkenler & & $\mathbf{n}$ & $\mathbf{\%}$ \\
\hline Cinsiyet & Kadın & 14 & 100.0 \\
& Erkek & 0 & 0.0 \\
Yaş & 30 yaş ve altı & 7 & 50.0 \\
& 30 yaş üstü & 7 & 50.0 \\
& 1 yıldan az & 0 & 0.0 \\
Öğretmenlik süresi & $1-5$ yıl & 3 & 21.4 \\
& 6-10 yıl & 9 & 64.3 \\
Özel eğitim ile ilgili eğitim & 11-20 yıll & 2 & 14.3 \\
alma durumu & Evet yıl üzeri & 0 & 0.0 \\
Daha önce sinıfınızda & Hayır & 11 & 78.6 \\
gelişimsel yetersizliği olan bir & Evet & 3 & 21.4 \\
çocuk olma durumu & Hayır & 11 & 78.6 \\
\hline
\end{tabular}

Tablo1'de görüldüğü üzere öğretmenlerin tamamı kadın ve evli olup 7'si 30 yaş ve altı, 7'si 30 yaş üstüdür. Üç öğretmen 1-5 yıl, 9 öğretmen 6-10 yıl ve 2 öğretmen 11-20 yıldır öğretmenlik mesleğini sürdürmektedir. On bir öğretmen özel eğitim ile ilgili eğitim alırken üç öğretmen özel eğitim ile ilgili herhangi bir eğitim almamıştır. On bir öğretmen daha önce gelişimsel yetersizliği olan çocuk ile çalışmışken üç öğretmenin sınıfında hiç gelişimsel yetersizliği olan çocuk olmamıştır.

Tablo 2. Katılımcı çocukların özellikleri

\begin{tabular}{llll}
\hline Değişkenler & & $\mathbf{n}$ & $\mathbf{\%}$ \\
\hline Gelişimsel yetersizliği olma & Evet & 16 & 50.0 \\
durumu & Hayır & 16 & 50.0 \\
& 4 & 1 & 3.1 \\
Yaş & 5 & 16 & 50.0 \\
& 6 & 13 & 40.6 \\
Cinsiyet & 7 & 2 & 6.3 \\
& Kiz & 15 & 46.9 \\
& Erkek & 17 & 53.1
\end{tabular}




\begin{tabular}{|c|c|c|c|}
\hline \multirow{2}{*}{ Zihin yetersizliği } & Var & 13 & 40.6 \\
\hline & Yok & 19 & 59.4 \\
\hline \multirow{2}{*}{ İşitme yetersizliği } & Var & 1 & 3.1 \\
\hline & Yok & 31 & 96.9 \\
\hline \multirow{2}{*}{ Görme yetersizliği } & Var & 0 & 0.0 \\
\hline & Yok & 32 & 100.0 \\
\hline \multirow{2}{*}{ Otizm spektrum bozukluğu } & Var & 0 & 0.0 \\
\hline & Yok & 32 & 100.0 \\
\hline \multirow{2}{*}{ Dil ve konuşma yetersizliği } & Var & 7 & 21.9 \\
\hline & Yok & 25 & 78.1 \\
\hline \multirow{2}{*}{ Öğrenme güçlüğü } & Var & 1 & 3.1 \\
\hline & Yok & 31 & 96.9 \\
\hline \multirow{2}{*}{ Fiziksel/Ortopedik yetersizlik } & Var & 1 & 3.1 \\
\hline & Yok & 31 & 96.9 \\
\hline
\end{tabular}

Katılımcı çocukların özellikleri Tablo 2'de verilmiştir. Buna göre katılımcı çocuk özellikleri şöyledir; 16 gelişimsel yetersizliği olan, 16 gelişimsel yetersizliği olmayan 32 çocuk çalışmaya katılmıştır. Bir çocuk 36-48, 16 çocuk 48-60, 13 çocuk 60-72 ve 2 çocuk 72-84 aylıktır. Çocukların 15'i kız, 17'si erkektir. Gelişimsel yetersizliği olan çocukların 13’ü zihin yetersizliğine, 7'si hem zihin yetersizliği hem dil konuşma yetersizliği, 1 çocuk işitme yetersizliğine, 1 çocuk fiziksel/ortopedik yetersizliğe, 1 çocuk da öğrenme güçlüğüne sahiptir. Gelişimsel yetersizliği olan çocukların tamamı Rehberlik Araştırma Merkezi tarafından herhangi bir tanı grubunda değerlendirilen çocuklardır. Sınıflarda bulunan çocuklardan gelişimsel yetersizliği olmayan bir çocuğu, öğretmen çok sessiz olmama veya çok aktif olmama koşuluna göre belirlemiştir.

\section{Veri Toplama Aracı}

Araştırmada erken çocukluk döneminde öğretmenlerin etkileşim davranışlarının çocukların gelişimsel yetersizliği olup olmama durumlarına göre incelenmesi amacıyla araştırmacılar tarafından, bu çalışma için geliştirilen “Öğretmen Etkileşim Davranışları Gözlem Formu” ve “Öğretmen ve Öğrenci Bilgi Formu” kullanılmıştır. Bu veri toplama araçları aşağıda ayrıntılı olarak açıklanmıştır.

\section{Öğretmen Etkileșim Davranıșları Gözlem Formu'nun Hazırlanması}

Öğretmen Etkileşim Davranışları Gözlem Formu (ÖEDGF) araştırmacı tarafindan alanyazın taraması yapılarak oluşturulmuştur. Gözlem formu geliştirilirken alan yazında etkileşim davranışlarını inceleyen araştırmalar (Ceber, 1998; Diken, 2009; Karaaslan, 2010; Toper Korkmaz, 2015; Töret, Özdemir ve Özkubat, 2015), öğretmen etkileşim davranışlarını inceleyen araştırmalar (Demir, 2016; König, 2009; Roorda, Koomen, Spilt, Thijs ve Oort, 2013; Rudasill ve Kaufman, 2009; Thijs, Koomen, Roorda ve Hagen, 2011;Trawick Smith ve 
Dziurgot, 2010; Tseng, 2015) ve öğretmen davranışlarını inceleyen araştırmalar (Akalın, 2007; Akalın, 2012; Sazak Pınar, 2009) gözden geçirilmiştir. Tarama sonucunda gözlem formunda yer alan 10 sözel veya sözel olmayan öğretmen etkileşim davranışına yer verilmiştir. ÖEDGF'nda her etkileşim davranışı gözlenebilir ve ölçülebilir şekilde tanımlanmış olup “evet (davranış gözlendi) ve hayır (davranış gözlenmedi) şeklinde puanlandırılmıştır. ÖEDGF'nda yer alan öğretmen etkileşim davranışları sırasıyla şöyledir: Çocuğun kendisine yönelttiği sözel veya sözel olmayan etkileşim girişimlerine sözel ya da sözel olmayan davranışlarla yanıt verir, çocuğa sözel ya da sözel olmayan bir uyaran sunar, çocuğa seçenek sunar, çocuğa dikkatini yöneltir/sürdürür, çocukla konuşurken ses tonunu uygun kullanır, çocukla fiziksel etkileşim kurar, çocuğa gereksinim duyduğunda yardım eder, çocuğu etkinliğe doğru yeniden yöneltir/yönlendirir, çocuğu akranı ile etkileşimi için yönlendirir, çocuğun olumlu davranışlarını onaylar. ÖEDGF için iki okul öncesi ve iki özel eğitim alanında yer alan dört uzman görüşüne başvurulmuştur. Uzmanlar ÖEDGF'nda yer alan etkileşim davranışlarını binişik olmama, birbirini dışta bırakma ve işlevsel tanımları bakımından değerlendirmiştir. Uzmanlardan elde edilen değerlendirmelerin sonucunda ÖEDGF'na son şekli verilmiştir.

Çalışmaya başlamadan önce bir pilot çalışma yapılmıştır. Pilot çalışmada katılımcı grubunun yer almadığı farklı üç okulda bulunan üç öğretmenin gelişimsel yetersizliği olan ve olmayan çocuklarla etkileşim davranışları incelenmiştir. Çalışmada gözlemler oyun etkinlikleri ve masa başı etkinlikleri sırasında yapılmış ve ÖEDGF’na göre değerlendirilmiştir. Pilot çalışma sonucunda elde edilen veriler doğrultusunda ÖEDGF'nda yer alan öğretmen etkileşim davranışları anlaşılırlık, amaca ve düzeye uygunluk bakımından değerlendirilmiş ve uygun hale getirilmiştir.

\section{Öğretmen ve Öğrenci Bilgi Formu’nun Hazırlanması}

Araştırmacı tarafından öğretmenlerin yaşı, cinsiyeti, medeni durumu, öğretmenlik süresi, özel eğitimle ilgili eğitim alma durumu ve daha önce sınıfında gelişimsel yetersizliği olan bir öğrenci olma durumunu içeren değişkenlerden oluşan "Öğretmen Bilgi Formu” ve çocuğun yaşı, cinsiyeti, gelişimsel yetersizliğine sahip olma durumunu içeren değişkenlerden oluşan “Öğrenci Bilgi Formu” oluşturulmuştur.

\section{Verilerin Toplanması}

Araştırmacı çalışma grubu kapsamında yer alan tüm okulların idarecileri ile görüşüp araştırma iznini sunmuş ve çalışmanın amacı, nasıl gerçekleştirileceği, avantajları ve dezavantajları hakkında bilgilendirmiştir. Okul idarecilerinden alınan onay doğrultusunda sınıfında gelişimsel yetersizliği olan çocuk bulunan okul öncesi öğretmenleri ve çocukların 
ailelerinden araştırma için gerekli izinler alınmıştır. Araştırmanın geçerliği ve güvenirliğini etkilememesi bakımından öğretmenleri bilgilendirme sırasında araştırmanın asıl amacı hakkında bilgi verilmemiştir. Araştırmacı tarafından danışman rehberliğinde belirlenen iki etkinlik araştırmaya gönüllü olarak katılacağını belirten öğretmenlere çalışmadan bir-iki hafta önce verilmiştir.

\section{Etkinliklerin Belirlenmesi}

Çalışmada verilerin toplanması sürecinde ölçülmek istenen amaca uygun iki okul öncesi eğitim etkinliği belirlenmiştir. Araştırmacı tarafından bir masa başı etkinliği bir de oyun etkinliği olmak üzere belirlenen etkinlikler farklı kaynaklar incelenerek alan yazında yer alan öğretmen etkileşim davranışları göz önünde bulundurulup Milli Eğitim Bakanlığı Okul Öncesi Eğitim Programı Etkinlik Kitabı'ndan (2013) seçilmiştir. Belirlenen iki etkinlik için bir okul öncesi ve bir özel eğitim alanında yer alan iki uzman görüşüne başvurulmuştur. Uzman görüşü ve bir ön çalışmadan sonra etkinliklerin uygunluğu tespit edilmiştir. Bu etkinlikler aşağıda ayrıntılı olarak açıklanmıştır.

\section{Masa Başı Etkinliği}

Belirlenen "Bizim Çizgilerimiz" adlı masa başı etkinliği sanat ve okuma yazmaya hazırlık becerileri etkinlik çeşididir. Etkinliğin öğrenme sürecinde öğretmen sınıf mevcuduna göre çocukları çeşitli gruplara ayırır. Her gruba bir beyaz büyük boy kağıt ve renkli keçeli kalemler verir. Gruptaki çocuklar sırayla keçeli kalemler ile kağıda düz, eğik, yuvarlak vb. çizgiler çizerler. Her çocuk arkadaşının kaldığı yerden çizgiyi devam ettirerek çizgi çalışmasını tamamlar. Çizgi çalışması tamamlandıktan sonra öğretmen her gruba renkli pastel boyalar vererek çizgilerin kesiştiği yerlerde oluşan şekilleri boyamalarını ister. Tüm gruplar boyamalarını bitirdikten sonra yapılan çalışmalar sınıfın bir köşesine asılır. Gruplar yaptıkları çalışmada ortaya çıkan şekiller üzerinde konuşur. Oluşan şekillerden üçgen, daire, kare, elips vb. geometrik şekillere dikkat çekilir. Grup üyeleri alkışlanır ve etkinlik sonlandırılır.

\section{Oyun Etkinliği}

Belirlenen "Günaydın" adlı etkinlik, Türkçe ve Oyun etkinlik çeşididir. Etkinliğin öğrenme sürecinde öğretmen bütün çocukları karşısına oturtur ve "Toprak Ev" adlı parmak oyununu oynatır. Çocuklar kutunun içinde olan çeşitli hayvan resimlerinden birer tane seçerler. Öğretmen çocukların seçtiği hayvan resimlerini sırtlarına yapıştırır. Çocuklar birbirlerinin sırtındaki hayvan resimlerini inceler ve yere yüz üstü uzanır. İlk oyunda öğretmen ebe olur ve çocukları sırtlarında bulunan hayvan ismine göre "günaydın karınca" diyerek omuzlarına dokunup uyandırır. Uyandırma sırasında öğretmen bazen solucan gibi sürünür, bazen 
kaplumbağa gibi yavaş yürür, bazen yüksek sesle bazen de fisıltı ile "günaydın" der. Uyanan çocuklar da öğretmenin arkasına dizilerek hareketlerini taklit ederler. Oyun bir tek çocuk kalana kadar devam ettirilir. En son uyandırılan çocuk ebe olur. Oyun bu şekilde tekrar ettirilir. Öğretmen hayvan resimlerini yan yana dizer. "Bu hayvanlar bir çiftlikte yaşıyorlarmış. Karınca dışında tüm hayvanlar sabah uyandıklarında birbirlerine günaydın diyorlarmış. Ama karınca hiç kimseye günaydın demiyormuş.” der. Öğretmen çocuklarla karıncanın neden günaydın demediği, günaydın demediğinde diğer hayvanların neler hissetmiş olabileceği, neden bu şekilde hissettikleri, günaydın demesi için karıncanın ve diğer hayvanların neler yaptığı hakkında konuşur ve etkinlik sonlandırılır.

\section{Etkinliklerin Uygulanması ve Gözlemlerin Yapılması}

Araştırmacı çalışmanın amacı ve niteliğine göre hazırlanmış çalışma etkinliklerini gözlem yapılmadan bir-iki hafta önce gönüllü öğretmenlere vermiş, etkinlikler hakkında öğretmenleri bilgilendirmiş ve materyalleri hazırlayacağını belirtmiştir. Etkinliklerin uygulanması ve gözlenmesi okul idarecilerinin ve öğretmenlerin uygun bulduğu gün ve saatlerde yapılmıştır. Etkinliklerin uygulanması için belirlenen zamanlarda masa başı etkinlikleri ve oyun etkinlikleri bazen aynı gün içinde farklı saatlerde uygulanmış, bazen de farklı günlerde uygulanmak üzere öğretmenler tarafından randevu verilmiştir. Beyaz kağıt, renkli keçeli kalemler, renkli pastel boyalar, çeşitli hayvan resimleri ve kutu hazırlanmıştır. Masa başı etkinlik zamanları ve oyun etkinlik zamanları belirlenip materyaller hazırlandıktan sonra etkinliklerin uygulanması ve gözlem sürecine başlanmıştır. On dört okul öncesi öğretmenin sınıfında farklı zamanlarda etkinliklerin uygulanması esnasında video kayıtları alınmıştır. Etkinlikler sırasında hazırlanan iki kamera tripod ile sınıfın farklı ortamlarına öğretmeni ve çocukları çeşitli açılardan alabilecek şekilde yerleştirilmiştir. Video kayıtları etkinliklerin uygulanma süresine bağlı olarak 15-40 dakika arası bir zaman diliminde alınmıştır. Sınıf ortamı düzenlenmiş, materyaller öğretmenin kolayca ulaşabileceği bir yere konulmuştur. Etkinlikler esnasında araştırmacı bazen sınıfın kamera açısına girmeyen bir köşesinde beklemiş, bazen de sınıfın dışında bir yerde beklemiştir. Alınan video kayıtları daha sonra veri toplama aracı olan gözlem formuna kaydedilmek üzere saklanmıştır.

\section{Öğretmen Etkileşim Davranışlarının Değerlendirilmesi}

Öğretmen etkileşim davranışlarının değerlendirilmesi için gözlemlerde elde edilen video kayıtları hazırlanan ÖEDGF'na göre doldurulmuştur. Her bir etkinlik videosu için "parçalı zaman aralığı kaydı" veri kayıt tekniği kullanılmıştır. Parçalı zaman aralığı kaydı, gözlem süresi eşit zaman aralıklarına bölünerek gözlem yapan kişinin bu zaman aralıklarında 
herhangi bir anında davranış gerçekleştiğinde kaydetmesi olarak tanımlanır (Tekin İftar, 2014). $\mathrm{Bu}$ araştırmada da parçalı zaman aralığı kaydı şöyle kullanılmış:

ÖEDGF'nda bulunan hedef davranışlar parçalı zaman aralığı kaydına göre 10 dakikalık 10'ar saniye aralıklara bölünerek her davranış için parçalı zaman aralığı kaydı veri toplama formu oluşturulmuştur. Gözlem formunda yer alan 10 hedef davranış için 10 parçalı zaman aralığı kaydı veri toplama formu oluşturulmuştur. Video kayıtlarında derslerin 10 dakikalık kesiti masa başı etkinliğinde öğretmenin gelişimsel yetersizliği olan çocukla etkileşim davranışları, masa başı etkinliğinde öğretmenin gelişimsel yetersizliği olmayan çocukla etkileşim davranışları, oyun etkinliğinde öğretmenin gelişimsel yetersizliği olan çocukla etkileşim davranışları ve oyun etkinliğinde öğretmenin gelişimsel yetersizliği olmayan çocukla etkileşim davranışları olarak ayrı ayrı izlenmiştir. Etkinliklerin uygulanma zamanları 15-40 dakika arasında sürdüğü için etkinliklerin 10 dakikalık kesiti etkinlik zamanına bağlı olarak değişmişstir. 30 dakikalık ders zamanı için dersin ilk ve son 10 dakikası dışındaki 10 dakikalık kesit gözlem için belirlenmiştir. Gözlem sırasında dersin 10 dakikalık kesitinde her bir 10 saniye için davranış gözlenmiş ise “+”, davranış gözlenmemiş ise “_“olarak işaretlenmiştir.

Gözlem formundaki hedef davranışlara göre oluşturulmuş parçalı zaman aralığı kaydı veri toplama formlarının tamamı her bir değişken için kaydedilmiştir. Araştırmacı tarafından Öğretmen Etkileşim Davranışları Parçalı Zaman Aralığı Kaydı Veri Toplama Formu oluşturulmuştur. Form "öğretmenin çocuk ile etkileşimi var”, "öğretmenin çocuk ile etkileşimi yok” şeklinde puanlandırılarak 10 dakikalık 10'ar saniye aralıklarla hazırlanmıştır. Bu form her bir değişken için işaretlenen hedef davranış veri toplama formlarına bakılarak kaydedilmiştir. Öğretmen dersin belirlenen 10 dakikalık kesitinde 10 saniye aralıklarda belirlenen hedef davranıştan birini veya bir kaçı gerçekleştirmiş ise "öğretmenin çocuk ile etkileşim var" (+), belirlenen hedef davranıştan birini gerçekleştirmemiş ise "öğretmenin çocuk ile etkileşimi yok" (-) şeklinde puanlandırılmıştır.

\section{Verilerin Analizi}

Araştırmada veriler betimsel analiz tekniğine göre çözümlenmiş elde edilen bulgular nicel betimsel analiz tekniğine uygun frekans ve yüzde hesaplamaları ile sunulmuştur. Araştırmada elde edilen veriler SPSS bilgisayar programına göre analiz edilmiştir. Öğretmenlerin masa başı ve oyun etkinlikleri sırasında gelişimsel yetersizliği olan ve olmayan çocuklarla etkileşim davranışları sıklığının farklılaşıp farklılaşmadığını belirlemek, öğretmenlerin her iki etkinlik biçimlerindeki sıra ortalamaları arasındaki farklar Mann Whitney-U Testi kullanılarak karşılaştırılmıştır. Mann Whitney-U Testi küçük örneklem 
gruplarında, iki aritmetik ortalama arasındaki farkın anlamlılığını test amacıyla kullanıldı̆̆ından tercih edilmiştir.

Bağımlı değişken güvenirliği için gözlemciler arası güvenirlik çalışması yapılmıştır. Gözlemciler arası güvenirlik, iki bağımsız gözlemcinin birbirinden bağımsız fakat eşzamanlı olarak hedef becerinin ne düzeyde gerçekleştiğine ilişkin yaptıkları değerlendirmelerin karşılaştırılmasıdır (Tekin İftar ve Kırcaali İftar, 2013). Araştırmanın gözlemciler arası güvenirlik verilerini belirlemek amacıyla "Gözlemciler Arası Güvenirlik Formu" hazırlanmıştır. İkinci gözlemci ve araştırmacının kaydettiği veriler Gözlemciler Arası Güvenirlik Formu'na işaretlenerek güvenirlik hesaplamaları yapılmıştır. Güvenirlik hesaplamaları [(Görüş birliği/Görüş birliği+Görüş ayrılığı)x100] göre yapılmıştır. Bağımlı değişken güvenirliğinde ikinci gözlemci özel eğitim alanında yüksek lisansını tamamlamış, doktora yapmaktadır. Veri toplama sürecinde her çocuk için iki etkinlik olmak üzere toplam 64 etkinlik kaydı alınmıştır. Bu kayıtların \%20'si olan 13 etkinlik kaydı ikinci bir gözlemci tarafından izlenmiş ve veri toplama formlarına kaydedilmiştir. Gözlemciler arası güvenirlik ÖEDGF'nda yer alan her bir etkileşim davranışına ayrı ayrı bakılarak hesaplanmıştır. Gözlemciler arası güvenirlik katsayıları Tablo 3'de verilmiştir:

Tablo 3. Gözlemciler arası güvenirlik katsayıları

\begin{tabular}{lcc}
\hline Hedef Davranış & Ortalama (\%) & $\begin{array}{c}\text { Puanlayıcılar } \\
\text { Arası Güvenirlik } \\
\text { Hesaplaması (\%) }\end{array}$ \\
\hline $\begin{array}{l}\text { 1.Çocuğun kendisine yönelttiği sözel veya sözel olmayan etkileşim } \\
\text { girişimlerine sözel ya da sözel olmayan davranışlarla yanıt verir. }\end{array}$ & 90 & \\
2. Çocuğa sözel ya da sözel olmayan bir uyaran sunar. & 95 & $82-98$ \\
3. Çocuğa seçenek sunar. & 89 & $92-99$ \\
4. Çocuğa dikkatini yöneltir/sürdürür. & 91 & $84-96$ \\
5. Çocukla konuşurken ses tonunu uygun kullanır. & 89 & $83-96$ \\
6. Çocukla fiziksel etkileşim kurar. & 88 & $85-98$ \\
7. Çocuğa gereksinim duyduğunda yardım eder. & 92 & $81-94$ \\
8. Çocuğu etkinliğe doğru yeniden yöneltir/yönlendirir. & 87 & $85-98$ \\
9. Çocuğu akranı ile etkileşimi için yönlendirir. & 90 & $80-94$ \\
10. Çocuğun olumlu davranışlarını onaylar. & 87 & $84-96$ \\
\hline
\end{tabular}

\section{Etik Kurul Kararı}

Abant İzzet Baysal Üniversitesi Sosyal Bilimlerde İnsan Araştırmaları Etik Kurulunun, 17/05/2016 tarihli ve 2016/03 sayılı toplantısında “Okul Öncesi öğretmenlerinin Sınıflarındaki Gelişim Yetersizliği Olan ve Olmayan Öğrencilerle Etkileşim Davranışlarının İncelenmesi” başlıklı çalışmanın etik kuralları ve ilkeleri çerçevesinde herhangi bir sakınca olmadığına karar verilmiştir. 


\section{Bulgular}

$\mathrm{Bu}$ bölümde erken çocukluk döneminde öğretmenlerin etkileşim davranışlarının çocukların gelişimsel yetersizliği olup olmama durumlarına göre incelenmesine yönelik toplanan verilerin analiz edilmesi ile elde edilen bulgulara yer verilmiştir.

\section{Öğretmenlerin Gelişimsel Yetersizliği Olan ve Olmayan Çocuklarla (Büyük Grup)} Masa Başı ve Oyun Etkinliği Sırasında Etkileşim Davranışlarının Sıklığına İlişkin

\section{Bulgular}

$\mathrm{Bu}$ çalışmada öğretmenlerin etkileşim davranışlarının sıklı̆̆ı çocukların gelişimsel yetersizliği olup olmama durumlarına göre incelenmiştir. Etkileşim davranışlarından 1. davranış olarak çocuğun kendisine yönelttiği sözel veya sözel olmayan etkileşim girişimlerine sözel ya da sözel olmayan davranışlarla yanıt verme, 2. davranış olarak çocuğa sözel ya da sözel olmayan bir uyaran sunma, 3. davranış olarak çocuğa seçenek sunma, 4. davranış olarak çocuğa dikkatini yöneltme/sürdürme, 5. davranış olarak çocukla konuşurken ses tonunu uygun kullanma, 6. davranış olarak çocukla fiziksel etkileşim kurma, 7. davranış olarak çocuğa gereksinim duyduğunda yardım etme, 8. davranış olarak çocuğu etkinliğe doğru yeniden yöneltme/yönlendirme, 9. davranış olarak çocuğu akranı ile etkileşimi için yönlendirme ve 10. davranış olarak çocuğun olumlu davranışlarını onaylama tanımlanmıştır. Her bir etkileşim davranışı masa başı seçilen etkinlikler esnasında ve oyun zamanında seçilen etkinlikler esnasında gözlenmiş, kayıt edilmiş ve analiz edilmiştir. Öğretmenlerin gelişimsel yetersizliği olan ve olmayan çocuklarla (büyük grup) masa başı ve oyun etkinliği sırasında etkileşim davranışlarının sıklığına ilişkin bulgular Tablo 4'de verilmiştir.

Tablo 4. Öğretmenlerin masa başı ve oyun etkinliği sırasında gelişimsel yetersizliği olan ve olmayan çocuklarla (büyük grup) etkileşim davranışları sıklığı

\begin{tabular}{|c|c|c|c|c|c|}
\hline Etkinlik & $\begin{array}{l}\text { Öğretmen Etkileşim Davranışları } \\
\text { Sıklığı }\end{array}$ & Min & Max & $\bar{x}$ & $\mathbf{S}_{\mathbf{x}}$ \\
\hline \multirow{11}{*}{ Masa Başı } & Tüm Davranışların Sıklığı & 1 & 40 & 13.16 & 7.84 \\
\hline & 1. Etkileşim Davranış1 Sıklığ1 & 0 & 24 & 5.06 & 5.59 \\
\hline & 2. Etkileşim Davranış1 Sıklı̆̆ & 0 & 24 & 6.16 & 5.69 \\
\hline & 3. Etkileşim Davranış1 Sıklığ1 & 0 & 0 & 0.00 & 0.00 \\
\hline & 4. Etkileşim Davranış1 Sıklığı & 1 & 36 & 13.06 & 7.41 \\
\hline & 5. Etkileşim Davranış1 Sıklı̆̆g & 0 & 21 & 8.00 & 5.94 \\
\hline & 6. Etkileşim Davranış1 Sıklığı & 0 & 12 & 1.34 & 2.42 \\
\hline & 7. Etkileşim Davranış1 Sıklı̆̆ & 0 & 17 & 1.59 & 3.55 \\
\hline & 8. Etkileşim Davranış1 Sıklığı & 0 & 13 & 1.56 & 3.11 \\
\hline & 9. Etkileşim Davranış1 Sıklığ1 & 0 & 1 & 0.09 & 0.30 \\
\hline & 10.Etkileşim Davranışı Sıklığ1 & 0 & 9 & 1.06 & 2.00 \\
\hline
\end{tabular}




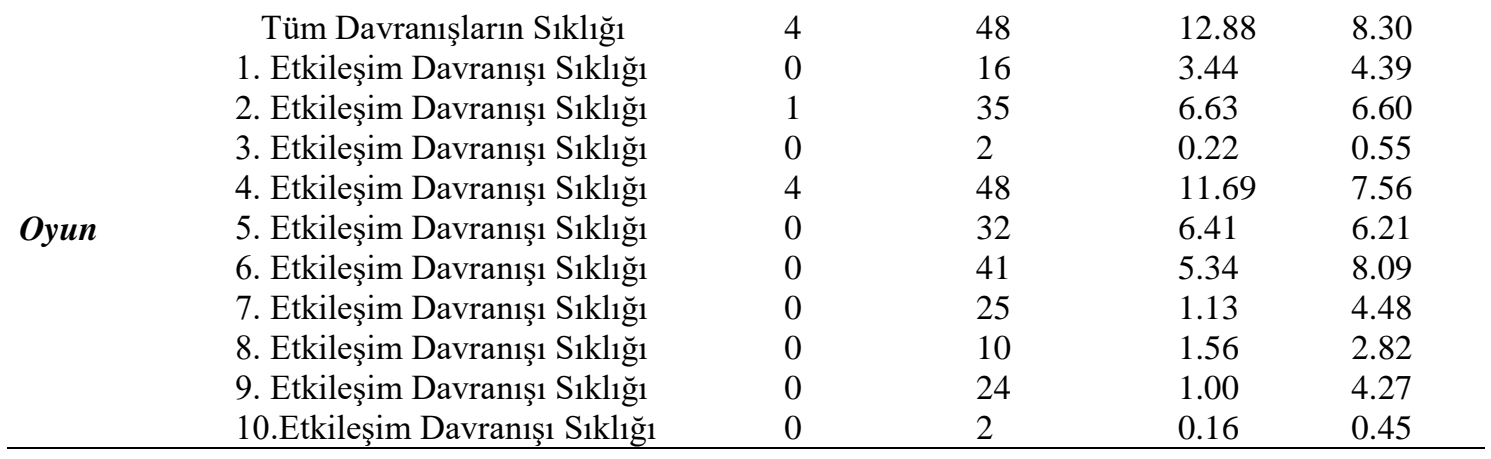

Tablo 4'e göre öğretmenlerin masa başı etkinliği ve oyun etkinliği sırasında gelişimsel yetersizliği olan ve olmayan çocuklarla (büyük grup) etkileşim davranışları sıklığına bakıldığında; öğretmenlerin masa başı etkinliği sırasında gelişimsel yetersizliği olan ve olmayan çocuklarla (büyük grup) etkileşim davranışları sıklığının ortalaması 13.16, oyun etkinliği sırasında ise 12.88 olarak görülmektedir. Öğretmenlerin masa başı ve oyun etkinliği sırasında gelişimsel yetersizliği olan ve olmayan çocuklarla (büyük grup) etkileşim davranışlarının alt boyutları incelendiğinde; masa başı etkinliği sırasında en sık etkileşim davranışının 4. etkileşim davranışı (çocuğa dikkatini yöneltme/sürdürme) olduğu, en az etkileşim davranışının ise 3. etkileşim davranışı (çocuğa seçenek sunma) olduğu, oyun etkinliği sırasında en sık gözlenen etkileşim davranışının 4. etkileşim davranışı (çocuğa dikkatini yöneltme/sürdürme) olduğu, en az etkileşim davranışının ise 10. etkileşim davranışı (çocuğun olumlu davranışlarını onaylama) olduğu ortaya çıkmaktadır.

Masa Başı Etkinlikleri Sırasında Öğretmenlerin Etkileşim Davranışlarının Sıklığında Çocukların Gelişimsel Yetersizliği Olup Olmama Durumlarına Göre Anlamlı Bir Fark Olup Olmadığına İlişkin Bulgular

Masa başı ve oyun etkinliği sırasında öğretmenlerin etkileşim davranışlarının sıklığını çocukların gelişimsel yetersizliği olup olmama durumlarına göre belirlemek amacıyla Öğretmen Etkileşim Davranışları Gözlem Formu'ndan (ÖEDGF) elde edilen veriler analiz edilmiştir. ÖEDGF'dan elde edilen puanların normal dağılım gösterip göstermediğini belirlemek amacıyla Kolmogorov Smirnov Testi kullanılmıştır. Öğretmenlerin masa başı ve oyun etkinliği sırasında gelişimsel yetersizliği olan ve olmayan çocuklarla etkileşim davranışları sıklığı Kolmogorov-Smirnov normallik testi sonuçlarına göre tüm puanların normal dağılım göstermediği ortaya çıkmıştır. Bu nedenle öğretmenlerin etkileşim davranışları sıklığının çocukların gelişimsel yetersizliği olup olmama durumlarına göre anlamlı bir şekilde 
farklılaşıp farklılaşmadığını belirlemek amacıyla nonparametrik bir test olan ilişkisiz ölçümler için kullanılan Mann Whitney U-Testi kullanılmıştır.

Masa başı etkinliği sırasında öğretmenlerin etkileşim davranışları sıklığının çocukların gelişimsel yetersizliği olup olmama durumları açısından karşılaştırılmasına ilişkin Mann Whitney-U testi sonuçları Tablo 5'te verilmiştir.

Tablo 5. Masa başı etkinliği sırasında öğretmenlerin etkileşim davranışları sıklığının çocukların gelişimsel yetersizliği olup olmama durumları açısından karşılaştırılmasına ilişkin sonuçları

\begin{tabular}{|c|c|c|c|c|c|c|}
\hline Etkinlik & $\begin{array}{l}\text { Öğretmen Etkileşim } \\
\text { Davranışları Sıklığı }\end{array}$ & & $\bar{x}$ & $S_{x}$ & $\mathbf{U}$ & $\mathbf{p}$ \\
\hline \multirow{22}{*}{ Masa Başı } & \multirow{2}{*}{ Tüm Davranışların Sıklığı } & Evet & 14.13 & 6.52 & \multirow{2}{*}{100.5} & \multirow{2}{*}{0.299} \\
\hline & & Hayır & 12.19 & 9.09 & & \\
\hline & \multirow{2}{*}{ 1. Etkileşim Davranışı Sıklığı } & Evet & 3.50 & 4.37 & \multirow{2}{*}{85.5} & \multirow{2}{*}{0.106} \\
\hline & & Hayır & 6.63 & 6.34 & & \\
\hline & \multirow{2}{*}{ 2. Etkileşim Davranışı Sıklığı } & Evet & 8.56 & 6.45 & \multirow{2}{*}{66.5} & \multirow{2}{*}{$0.020 *$} \\
\hline & & Hayır & 3.75 & 3.61 & & \\
\hline & \multirow{2}{*}{ 3. Etkileşim Davranışı Sıklığı } & Evet & 0.00 & 0,00 & \multirow{2}{*}{128.0} & \multirow{2}{*}{1.000} \\
\hline & & Hayır & 0.00 & 0,00 & & \\
\hline & \multirow{2}{*}{ 4. Etkileşim Davranışı Sıklığı } & Evet & 14.31 & 6.49 & \multirow{2}{*}{94.0} & \multirow{2}{*}{0.199} \\
\hline & & Hayır & 11.81 & 8.24 & & \\
\hline & \multirow{2}{*}{ 5. Etkileşim Davranışı S1klığ } & Evet & 9.75 & 6.15 & \multirow{2}{*}{81.5} & \multirow{2}{*}{0.079} \\
\hline & & Hayır & 6.25 & 5.34 & & \\
\hline & \multirow{2}{*}{ 6. Etkileşim Davranışı Sıklığı } & Evet & 2.19 & 3.12 & \multirow{2}{*}{78.0} & \multirow{2}{*}{$0.040 *$} \\
\hline & & Hayır & 0.50 & 0.89 & & \\
\hline & \multirow{2}{*}{ 7. Etkileşim Davranışı Sıklığı } & Evet & 3.19 & 4.53 & \multirow{2}{*}{48.0} & \multirow{2}{*}{$0.000^{*}$} \\
\hline & & Hayır & 0.00 & 0.00 & & \\
\hline & \multirow{2}{*}{ 8. Etkileşim Davranışı Sıklığı } & Evet & 2.75 & 4.04 & \multirow{2}{*}{57.0} & \multirow{2}{*}{$0.004 *$} \\
\hline & & Hayır & 0.38 & 0.81 & & \\
\hline & \multirow{2}{*}{ 9. Etkileşim Davranışı Sıklığı } & Evet & 0.13 & 0.34 & \multirow{2}{*}{120.0} & \multirow{2}{*}{0.551} \\
\hline & & Hayır & 0.06 & 0.25 & & \\
\hline & \multirow{2}{*}{ 10. Etkileşim Davranışı Sıklığı } & Evet & 1.00 & 1.59 & \multirow{2}{*}{112.5} & \multirow{2}{*}{0.509} \\
\hline & & Hayır & 1.13 & 2.39 & & \\
\hline
\end{tabular}

Tablo 5'te masa başı etkinliği sırasında öğretmenlerin etkileşim davranışları sıklığının çocukların gelişimsel yetersizliği olup olmama durumları bakımından farklılaşıp farklılaşmadığını belirlemek amacıyla yapılan Mann Whitney U-Testi sonuçlarında masa başı etkinliği sırasında öğretmenlerin tüm etkileşim davranışları sıklığında çocukların gelişimsel yetersizliği olup olmama durumları bakımından anlamlı bir fark olmadığı $(U=100.5 ; p=0.299)$ görülmüştür. Etkileşim davranışları arasında masa başı etkinliğinde en anlamlı fark bulunan etkileşim davranışının "2. etkileşim davranışı (çocuğa sözel ya da sözel olmayan bir uyaran sunma) ( $U=66.5 ; p=0.20)$, 6. etkileşim davranışı (çocukla fiziksel etkileşim kurma) $(U=78.0$; $\mathrm{p}=0.040)$, 7. etkileşim davranışı (çocuğa gereksinim duyduğunda yardım etme) $(U=48.0$; 
p=0.000), ve 8. etkileşim davranışı (çocuğu etkinliğe doğru yeniden yöneltme/yönlendirme) (U=57.0; p=0.004)" olduğu ortaya çıkmıştır. Gelişimsel yetersizliği olan çocuklarda 2. etkileşim davranışı (çocuğa sözel ya da sözel olmayan bir uyaran sunma) sıklığı ortalamasının (8.56), gelişimsel yetersizliği olmayan çocuklarda ortalamasının (3.75) olduğu görülmüştür. 6. etkileşim davranışı (çocukla fiziksel etkileşim kurma) sıklığı ortalamasının gelişimsel yetersizliği olan çocuklarda (2.19), gelişimsel yetersizliği olmayan çocuklarda ise (0.50) olduğu ortaya koyulmuştur. 7. etkileşim davranışı (çocuğa gereksinim duyduğunda yardım etme) sıklığı ortalamasının gelişimsel yetersizliği olan çocuklarda (3.19), gelişimsel yetersizliği olmayan çocuklarda (0.00) olduğu görülmüştür. 8. etkileşim davranışı (çocuğu etkinliğe doğru yeniden yöneltme/yönlendirme) sıklığı ortalamasının gelişimsel yetersizliği olan çocuklarda (2.75), gelişimsel yetersizliği olmayan çocuklarda (0.38) olduğu bulunmuştur.

\section{Oyun Etkinlikleri Sırasında Öğretmenlerin Etkileşim Davranışlarının Sıklığında} Çocukların Gelişimsel Yetersizliği Olup Olmama Durumlarına Göre Anlamlı Bir Fark

\section{Olup Olmadığına İlişkin Bulgular}

Oyun etkinliği sırasında öğretmenlerin etkileşim davranışları sıklığının çocukların gelişimsel yetersizliği olup olmama durumları açısından karşılaştırılmasına ilişkin Mann Whitney-U testi sonuçları Tablo 6'da verilmiştir.

Tablo 6. Oyun etkinliği sırasında öğretmenlerin etkileşim davranışları sıklığının çocukların gelişimsel yetersizliği olup olmama durumları açısından karşılaştırılmasına ilişkin sonuçları

\begin{tabular}{|c|c|c|c|c|c|c|}
\hline Etkinlik & $\begin{array}{l}\text { Öğretmen Etkileşim } \\
\text { Davranışları Sıklığı }\end{array}$ & & $\bar{x}$ & $\mathbf{S}_{\mathbf{x}}$ & $\mathbf{U}$ & $\mathbf{p}$ \\
\hline \multirow{20}{*}{ Oyun } & \multirow{2}{*}{ Tüm Davranışların Sıklığı } & Evet & 13.31 & 11.33 & \multirow{2}{*}{94.0} & \multirow{2}{*}{0.198} \\
\hline & & Hayır & 12.44 & 3.67 & & \\
\hline & \multirow{2}{*}{ 1. Etkileşim Davranışı Sıklığı } & Evet & 2.94 & 4.70 & \multirow{2}{*}{92.5} & \multirow{2}{*}{0.174} \\
\hline & & Hayır & 3.94 & 4.15 & & \\
\hline & \multirow{2}{*}{ 2. Etkileşim Davranışı Sıklığ1 } & Evet & 8.44 & 8.56 & \multirow{2}{*}{91.0} & \multirow{2}{*}{0.160} \\
\hline & & Hayır & 4.81 & 3.15 & & \\
\hline & \multirow{2}{*}{ 3. Etkileşim Davranışı Sıklığı } & Evet & 0.31 & 0.70 & \multirow{2}{*}{118.0} & \multirow{2}{*}{0.551} \\
\hline & & Hayır & 0.13 & 0.34 & & \\
\hline & \multirow{2}{*}{ 4. Etkileşim Davranışı Sıklığ1 } & Evet & 12.00 & 10.32 & \multirow{2}{*}{95.5} & \multirow{2}{*}{0.217} \\
\hline & & Hayır & 11.38 & 3.38 & & \\
\hline & \multirow{2}{*}{ 5. Etkileşim Davranışı Sıklığı } & Evet & 7.44 & 8.05 & \multirow{2}{*}{118.5} & \multirow{2}{*}{0.719} \\
\hline & & Hayır & 5.38 & 3.54 & & \\
\hline & \multirow{2}{*}{ 6. Etkileşim Davranışı Sıklığı } & Evet & 6.75 & 10.67 & \multirow{2}{*}{125.5} & \multirow{2}{*}{0.923} \\
\hline & & Hayır & 3.94 & 4.15 & & \\
\hline & \multirow{2}{*}{ 7. Etkileşim Davranışı Sıklığı } & Evet & 2.13 & 6.26 & \multirow{2}{*}{103.0} & \multirow{2}{*}{0.136} \\
\hline & & Hayir & 0.13 & 0.50 & & \\
\hline & \multirow{2}{*}{ 8. Etkileşim Davranışı Sıklığ1 } & Evet & 2.00 & 3.10 & \multirow{2}{*}{114.5} & \multirow{2}{*}{0.566} \\
\hline & & Hayır & 1.13 & 2.53 & & \\
\hline & \multirow{2}{*}{ 9. Etkileşim Davranışı Sıklığı } & Evet & 1.63 & 5.99 & \multirow{2}{*}{128.0} & \multirow{2}{*}{1.000} \\
\hline & & Hayır & 0.38 & 1.02 & & \\
\hline
\end{tabular}




\begin{tabular}{llllll} 
10.Etkileşim Davranışı Sıklığ & Evet & 0.13 & 0.50 & \multirow{2}{*}{113.5} & \multirow{0}{*}{$\mathbf{0 . 3 4 1}$} \\
& Hayır & 0.19 & 0.40 & \\
\hline
\end{tabular}
${ }^{*} \mathbf{p}<\overline{\mathbf{0 , 0 5}}$

Tablo 6 incelendiğinde oyun etkinliği sırasında öğretmenlerin etkileşim davranışları sıklığının çocukların gelişimsel yetersizliği olup olmama durumları bakımından farklılaşıp farklılaşmadığını belirlemek amacıyla yapılan Mann Whitney U-Testi sonuçlarına göre, oyun etkinliği sırasında öğretmenlerin tüm etkileşim davranışları sıklığında çocukların gelişimsel yetersizliği olup olmama durumları bakımından anlamlı bir fark olmadığı $(U=94.0 ; p=0.198)$ görülmektedir. Ancak 1. etkinlik davranışı (çocuğun kendisine yönelttiği sözel veya sözel olmayan etkileşim girişimlerine sözel ya da sözel olmayan davranışlarla yanıt verme) ve 10 . etkileşim davranışı (çocuğun olumlu davranışlarını onaylama) dışında diğer tüm davranışların sıklığı ortalamasının gelişimsel yetersizliği olan çocuklarda daha fazla olduğu görülmektedir.

\section{Tartışma, Sonuç ve Öneriler}

$\mathrm{Bu}$ çalışmanın amacı erken çocukluk döneminde öğretmenlerin etkileşim davranışlarının çocukların gelişimsel yetersizliği olup olmama durumlarına göre incelenmesidir. Bu amaç doğrultusunda "Öğretmen Etkileşim Davranışları Gözlem Formu ve Öğretmen Öğrenci Bilgi Formu” ile veriler toplanmış ve araştırmanın alt amaçlarına göre analiz edilerek elde edilen bulgular literatür 1şığında tartışılmıştır.

Çalışmanın ilk bulguları öğretmenlerin gelişimsel yetersizliği olan ve olmayan (büyük grup) çocuklarla masa başı ve oyun etkinliği sırasında etkileşim davranışlarının sıklığına ilişkin elde edilen bulgulardır. Bu bulgular incelendiğinde öğretmenlerin masa başı ve oyun etkinliği sırasında en sık kullandığı ilk üç davranış "sözel ya da sözel olmayan uyaran sunma, çocuğa dikkatini yöneltme/sürdürme ve çocukla konuşurken ses tonunu uygun kullanma" davranışları olduğu ortaya çıkmıştır. Öğretmenlerin en az tercih ettiği ilk üç davranış ise "çocuğa seçenek sunma, çocuğu akranı ile etkileşimi için yönlendirme, çocuğun olumlu davranışlarını onaylama" olarak saptanmıştır. Öğretmenlerin etkinlikler sırasında öğrencilerin problem davranışlarını kontrol edemediği (Kargın, Acarlar ve Sucuoğlu, 2005) buna karşın problem davranışları azaltmak için sözel uyaran verdikleri, dikkatini yönelttikleri ve konuştukları ortaya koyulmuştur (Batu ve Özen, 1997). Bu durum öğretmenlerin sözel ya da sözel olmayan uyaran sunma, çocuğa dikkatini yöneltme/sürdürme ve çocukla konuşurken ses tonunu uygun kullanma davranışlarını çok sık kullanmasının nedeni olarak söylenebilir.

Araştırmanın bu bulgusu König'in (2009) bulgularıyla tutarlılık göstermektedir. König (2009) öğretmenlerin öğrencileriyle etkileşimlerinde dönüt verme, yorum yapma, göz kontağ1 
kurma ve sürdürme, bekleme ve dinleme etkileşim davranışlarını yoğunluklu olarak kullandığını ortaya koymuştur. Bu araştırmada da öğretmenlerin en çok tercih ettiği etkileşim davranışlarının "çocuğa dikkatini yöneltme/sürdürme ve sözel veya sözel olmayan uyaran sunma" olarak bulunması sonuçların tutarlılık gösterdiğini kanıtlar niteliktedir. Çalışmada elde edilen bulgularda öğretmenlerin çocuklarla etkileşimlerinde "çocuğun olumlu davranışlarını onaylama” davranışını en az tercih ettiği görülmektedir. Çalışmanın bu bulgusu (Akalın, 2007; Sazak Pınar, 2009; Sazak Pınar ve Güner Yıldız, 2013) araştırma sonuçları ile tutarlılık göstermektedir. Akalın'ın (2007) çalışmasında sonuçlar, öğretmenlerin öğrencilerin ne akademik ne sosyal becerilerini ödüllendirdiklerini göstermiştir. Sazak Pınar'ın (2009) araştırmasında kaynaştırma sınıfı ortamlarında öğretmenlerin öğrencilerin sosyal becerilerini hiç ödüllendirmedikleri ortaya koyulmuştur. Sazak Pınar ve Güner Yıldız'ın (2013) öğretmenlerin onaylama ve onaylamama davranışlarını incelediği bir çalışmasında öğretmenlerin onaylamama davranışlarını onaylama davranışlarına oranla daha sık kullandığı bulunmuştur (Sazak Pınar ve Güner Yıldız, 2013). Bu çalışmada da öğretmenlerin masa başı ve oyun etkinliği sırasında etkileşim davranışları sıklığına bakıldığında öğretmenlerin etkileşimlerde çocuğun olumlu davranışlarını onaylama davranışını çok az kullandığı saptanmıştır. Öğretmenlerin onaylama davranışlarını çok az kullanmasına yönelik sonuçlar birbirini destekler niteliktedir.

Çalışmanın ikinci bulguları masa başı ve oyun etkinliği sırasında öğretmenlerin etkileşim davranışları sıklığında çocukların gelişimsel yetersizliği olup olmama durumlarına göre anlamlı bir fark olup olmadığını incelenmeye yöneliktir. Çalışmada genel olarak öğretmenlerin çocukların gelişimsel yetersizliği olup olmamalarına göre etkileşim davranışları sıklığında anlamlı bir fark olmasa da etkileşim davranışlarının alt boyutlarında anlamlı farklılıklar görülmüştür. Etkileşim davranışlarının alt boyutlarına ilişkin sonuçlarda masa başı etkinliği sırasında öğretmenlerin "çocuğa sözel ya da sözel olmayan uyaran sunma, çocukla fiziksel etkileşim kurma, çocuğa gereksinim duyduğunda yardım etme ve çocuğu etkinliğe doğru yeniden yöneltme/yönlendirme" davranışları sıklığında anlamlı bir fark ortaya çıkmıştır.

Öğretmenlerin gelişimsel yetersizliği olan çocuklarla etkileşimlerinde gelişimsel yetersizliği olmayan çocuklara göre daha çok “çocuğa gereksinim duyduğunda yardım etme, çocuğa sözel ya da sözel olmayan uyaran sunma, çocukla fiziksel etkileşim kurma ve çocuğu etkinliğe doğru yeniden yöneltme/yönlendirme" davranışlarını kullandığı sonucuna ulaşılmıştır. Bu durumun çocukların herhangi bir yetersizliğe sahip olmasından dolayı daha çok yardıma ihtiyaç duyması (Scruggs ve Mastropieri, 1996) ve daha fazla problem davranış 
göstermesinden (Küçükahmet, 2004) kaynaklandığg düşünülmektedir. Çiftçi, Yıkmış ve Altun (2001) ve Sazak Pınar ve Güner Yıldız'ın (2013) yaptığı çalışmaların bulguları öğretmenlerin kaynaştırma sınıflarında gelişimsel yetersizliği olan öğrenciyi daha az fark edip tepki verdiği ortaya koyulmuştur. Bu bulguların araştırma sonuçları ile örtüşmediği görülmektedir. Hagekull ve Hammarberg (2004) çalışmasında duygu davranış bozukluğu olan öğrencilerin öğretmenlerin etkileşim davranışlarını etkilediği sonucuna ulaşmıştır. Öğretmenlerin sözel veya sözel olmayan uyaran sunma, çocukla fiziksel etkileşim kurma, çocuğa gereksinim duyduğunda yardım etme ve çocuğu etkinliğe doğru yeniden yöneltme/yönlendirme davranışlarının gelişimsel yetersizliği olup olma durumuna göre farklılaşması bulguları, bu çalışmanın sonuçlarını destekler niteliktedir. Ayrıca diğer bir bulguda ise öğretmenlerin oyun etkinliği sırasında etkileşim davranışları sıklığının gelişimsel yetersizliği olup olmama durumuna göre farklılaşmadığı ortaya çıkmıştır. Bu durumun oyun etkinliği sırasında öğretmenlerin çocuklarla daha az bireysel etkileşimlerde bulunması ve çocukların etkinliğine daha az müdahale etmesinden kaynaklandığı düşünülmektedir.

Alan yazına bakıldığında Roorda ve diğerleri (2013) ve Nelson ve Robert'ın (2000) yaptığı çalışmaların bulguları araştırma sonuçları ile örtüşmemektedir. Roorda ve diğerleri (2013) çalışmasında duygu davranış bozukluğu olan öğrencilerin öğretmen etkileşim davranışlarını etkilediğini ortaya koymuştur. Araştırmaya göre öğretmenlerin yüksek düzeyde içedönük davranışlar gösteren öğrencilerle etkileşimlerinde daha yakınlık ve kontrollü davranışlar gösterdiği bulunmuştur. Yüksek düzeyde dışadönük davranışlar gösteren öğrencilerle etkileşimlerinde ise daha az yakınlık davranışları gösterdiği bulunmuştur (Roorda ve diğ., 2013). Nelson ve Robert'ın (2000) genel eğitim sınıflarında yaptığı 3 yıllık çalışmasında ise öğretmenlerin etkileşim davranışlarını öğrencilerin duygusal davranışsal problemlere sahip olma durumunun etkilediği bulunmuştur. Araştırma sonuçları Çiftçi ve diğerleri (2001) ve Akalın'ın (2007) çalışma sonuçları ile örtüşmektedir. Çiftçi ve diğerleri (2001) çalışmasında öğretmen davranışlarının öğrencilerin gelişimsel yetersizliği olup olmama durumuna göre farklılaşıp farklılaşmadığını incelemiştir. Sonuçlar öğretmen davranışlarının öğrencilerin gelişimsel yetersizliği olup olmama durumlarına göre farklılaşmadığını göstermiştir. Akalın (2007) da çalışmasında öğretmenlerin gelişimsel yetersizliği olan ve olmayan öğrencilerle davranışları arasında anlamlı bir fark olmadığını bulmuştur.

Özetle araştırma sonuçlarında öğretmenlerin en sık "sözel ya da sözel olmayan uyaran sunma, çocuğa dikkatini yöneltme/sürdürme ve çocukla konuşurken ses tonunu uygun kullanma” davranışlarını, en az “çocuğa seçenek sunma, çocuğu akranı ile etkileşimi için 
yönlendirme, çocuğun olumlu davranışlarını onaylama” davranışlarını kullandığı ortaya çıkmıştır. Masa başı ve oyun etkinliği sırasında öğretmenlerin genel etkileşim davranışları sıklığında çocukların gelişimsel yetersizliği olup olmama durumlarına göre anlamlı bir fark bulunmamıştır. Fakat etkileşim davranışlarının alt boyutlarına bakıldığında masa başı etkinliği sırasında "çocuğa sözel ya da sözel olmayan uyaran sunma, çocukla fiziksel etkileşim kurma, çocuğa gereksinim duyduğunda yardım etme ve çocuğu etkinliğe doğru yeniden yöneltme/yönlendirme" davranışları sıklığında anlamlı bir fark olduğu ortaya çıkmıştır. Öğretmenlerin gelişimsel yetersizliği olan çocuklarla etkileşimlerinde bu davranışları daha sık kullandığı saptanmıştır. Bu çalışmanın bazı sınırlılıkları bulunmaktadır. İlk olarak araştırma verilerinin toplanmasında etkinliklerin çeşidi ve gözlem süresi çalışmanın bir sınırlılığı olarak görülmektedir. İleri araştırmalara farklı etkinlik alanları ve daha uzun süreli gözlemlerle araştırmalar yapılması önerilebilir. İkinci bir sınırlılık ise araştırmada gözlem verilerinin toplanmasında okul idarecilerinden, öğretmenlerden ve çocukların ailelerinden gerekli izinlerin alınmasında güçlükler yaşanmasıdır.

Sonuç olarak bu araştırma Türkiye'de erken çocukluk dönemimde öğretmenlerin gelişimsel yetersizliği olan ve olmayan çocuklarla etkileşim davranışlarını inceleyen ve karşılaştıran ilk çalışma olması bakımından önemlidir. Daha önce okul öncesi öğretmenlerin etkileşim davranışları üzerinde bir programın etkililiğini inceleyen bir araştırma yapılmıştır (Demir, 2016). Fakat bu araştırmada öğretmenlerin gelişimsel yetersizliği olan ve olmayan çocuklarla etkileşim davranışlarının sıklığına bakılmamıştır. Bu araştırma öğretmenlerin etkileşimlerde en sık kullandığı veya en az kullandığı davranışları belirleme, etkileşim davranışları sıklığının gelişimsel yetersizliği olup olmama durumuna göre farklılaşıp farklılaşmadığını ortaya koyma bakımından önemlidir.

\section{Makalenin Bilimdeki Konumu}

\section{Özel Eğitim Bölümü/ Zihin Engellilerin Eğitimi}

\section{Makalenin Bilimdeki Özgünlüğü}

$\mathrm{Bu}$ araştırma kuramsal ve uygulamalar açısından önem taşımaktadır. Yurt dışında öğretmen çocuk etkileşimlerini inceleyen birçok araştırma yapılmış ancak yurt içi çalışmalarında öğretmen çocuk etkileşimini inceleyen çalışmalar sınırlı sayıdadır. Yapılacak bu çalışma ilgili literatürdeki bir eksikliği gidermeye yönelik katkı sunacağından dolayı önemli görülmektedir. Çalışmada öğretmenlerin gelişimsel yetersizliği olan ve olmayan çocuklarla (büyük grup) etkileşim davranışları sıklığının incelenmesi öğretmenlerin çocukların etkileşimlerinin ve öğretimsel desteğinin niteliğini belirleme açısından önemlidir. Erken 
çocukluk döneminde öğretmenlerin sınıf içinde özellikle gelişimsel yetersizliği olan çocuklarla etkileşim davranışları, bu çocuklara uygun öğrenmeler sağlayarak sınıf içindeki etkileşimlerini artırır. Öğretmenlerin etkileşim davranışlarının gelişim yetersizliği olup olma durumuna göre farklılaşıp farklılaşmadığını belirleyen bu çalışmanın, öğretmenlerin farkındalığını artırarak gelişimsel yetersizliği olan çocuklara karşı olumlu tutum geliştirmelerine katkı sağlayacağı düşünülmektedir.

\section{Kaynaklar}

Acarlar, F. (2013). Kaynaştırma modeli ve özel gereksinimli çocukların özellikleri. B. Sucuoğlu ve H. Bakkaloğlu (Ed.), Okul öncesinde kaynaştırma (ss. 21-74). Ankara: Kök Yayınc1lık.

Akalın, S. (2007). İlköğretim birinci kademedeki sınıf öğretmenleri ile kaynaştırma öğrencisi olan ve olmayan öğrencilerin sınıf içi davranışlarının incelenmesi. Yayımlanmamış yüksek lisans tezi, Ankara Üniversitesi, Eğitim Bilimleri Enstitüsü, Ankara.

Akalın, S. (2012). Bilgilendirme ve performans geribildirimine dayalı sinıf yönetimi müdahale programının kaynaştırma sınıflarındaki öğretmen-öğrenci çifti çıktıları üzerindeki etkileri. Yayımlanmamış doktora tezi, Ankara Üniversitesi, Eğitim Bilimleri Enstitüsü, Ankara.

Artan, İ. ve Uyanık Balat, G. (2003). Okul öncesi eğitimcilerinin entegrasyona ilişkin bilgi ve düşüncelerinin incelenmesi. Kastamonu Eğitim Dergisi, 11(1), 65-80.

Arı, M. (2005). Türkiye'de erken çocukluk eğitimi ve kalitenin önemi. M. Sevinç (Ed.), Erken çocuklukta gelişim ve eğitimde yeni yaklaşımlar içinde (ss. 31-35). İstanbul: Morpa yayıncilik.

Avcı, N. ve Ersoy, Ö. (2002). Okul öncesi dönemde entegrasyonun önemi ve uygulamalarda dikkat edilecek noktalar. Milli Eğitim Dergisi, 144, 68-70.

Barnett, W. S. (1995). Long term effects of early childhood programs on cognitive school outcomes. The Future of Children: Long Term Outcomes of Early Childhood Programs, 5, 25-50.

Başar, H. (1998). Sınıf yönetimi. Ankara: MEB Yayınları.

Batu, S. ve Özen, A. (Eylül, 1997). Sınıf öğretmenlerinin sınıf kontrolüne yönelik sorunlarının ve gereksinim duydukları destek hizmet türlerinin belirlenmesi. IV. Ulusal Eğitim Bilimleri Kongresi, Sözlü Bildiri, Eskişehir. 
Batu, S. (2010). Erken çocukluk eğitiminde kaynaştırma. İ.H. Diken (Ed.), Erken çocukluk ĕ̌itimi (ss. 520-537). Ankara: Pegem Akademi.

Bertan, M., Haznedaroğlu, D.,Koln, K., Yurdakök, K. ve Doğan Güçiz, B. (2009). Ülkemizde erken çocukluk gelişimine ilişkin yapılan çalışmaların derlenmesi (2000-2007). Çocuk Sağlı̆̆l ve Hastalıkları Dergisi, 52(1), 1-8.

Bradley Scott, M.A. (1998). “Snapping synapses in the early years”, Intercultural Development Research Association (IDRA) Newsletter. <http://www.idra.org/ newslttr/1998/Apr/Bradley.htm> 29.08.2017 tarihinde erişildi.

Ceber, H. (1998). Normal ve zihinsel engelli bebeklerde anne-bebek etkileşiminin karşılaştırmalı olarak incelenmesi. Yayımlanmamış yüksek lisans tezi, Ankara Üniversitesi, Sosyal Bilimler Enstitüsü, Ankara.

Çifci, İ., Yıkmış, A. ve Akbaba Altun, S. (2001). Kaynaştırma sınıflarında çalışan öğretmenlerin kaynaştırılmış ögrencilere yönelik pekiştireç kullanma durumlarının belirlenmesi. XI. Ulusal Özel Eğitim Kongresi, Sözlü Bildiri, Konya.

Demir, Ş. (2016). Öğretmen eğitimi programının kaynaştırma uygulamaları yürütülen okul öncesi sinıflardaki ögretmen ve özel gereksinimli çocuklar üzerindeki etkileri. Yayımlanmamış doktora tezi, Ankara Üniversitesi, Eğitim Bilimleri Enstitüsü, Ankara. Diken, Ö. (2009). Ebeveyn davranışını değerlendirme ölçeği ve çocuk davranışını değerlendirme ölçeği'nin geçerlik ve güvenirlik çalışmaları. Yayımlanmamış doktora tezi, Anadolu Üniversitesi, Sağl1k Bilimleri Enstitüsü, Eskişehir.

Ekiz, D. (2003). Eğitimde araştırma yöntem ve metodlarına giriş: Nitel, nicel ve eleştirel kuram metodolojileri. Ankara: Anı Yayınc1lık.

Elicker, J. \& Fortner Wood, C. (1995). Research in review. Adult-child relationships in early childhood settings. Young Children, 51(1), 69-78.

Erdoğan, S. (2010). Erken çocukluk döneminde kurum çeşitleri. İ. H. Diken (Ed.), Erken Çocukluk Eğitimi (ss. 362-372). Ankara: Pegem Akademi.

Ersoy, Ö. ve Avc1, N. (2001). Özel gereksinimi olan çocuklar ve eğitimleri. İstanbul: YA-PA Yayın.

File, N. \& Kontos, S. (1992). Indirect service delivery through consultation: Review and implications for early intervention. Journal of Early Intervention, 16(3), 221-233. Individuals with Disabilities Education Act of 2004. https:/www.gpo.gov/fdsys/pkg/PLAW108publ446/html/PLAW-108publ446.htm. 30.08.2017 tarihinde erişildi. 
Hagekull, B. \& Hammarberg, A. (2004). The role of teachers’ perceived control and children’s characteristics in interactions between 6-year-olds and their teachers. Scandinavian Journal of Psychology, 45, 301-312.

Henninger, W. R. \& Gupta, S. S. (2014). How do children benefit from inclusion? In S. S. Gupta, W. R. Henninger, IV \& M. E. Vinh (Eds.), First steps to preschool inclusion: How to jumpstart your programwide plan (pp. 33-61). Baltimore, MD: Paul H. Brookes Publishing.

Hamre, B. K. \& Pianta, R. C. (2005). Can instructional and emotional support in the firstgrade classroom make a difference for children at risk of school failure? Child Development, 76, 949-967.

Hamre, B., Hatfield, B., Pianta, R. \& Jamil, F. (2014). Evidence for general and domainspecific elements of teacher-child interactions: associations with preschool children's development. Child Development, 85(3), 1257-1274.

Howes, C. \& Smith, E. (1995). Children and their child care teachers: profiles of relationships. Social Development, 4, 44-61.

Howes, C. (1997). Children's experiences in center-based care as a function of teacher background and adult: child ratio. Merill-Palmer Quarterly, 43(3), 404-425.

Johnston, P. (2010). RTI in Literacy: Responsive and compherensive. International Reading Association, USA.

Karaaslan, Ö. (2010). Etkileşime dayalı erken eğitim programı'nın (edep) gelişimsel yetersizliğe sahip çocuklar ve anneleri üzerindeki etkililiği. Yayımlanmamış doktora tezi, Anadolu Üniversitesi, Eğitim Bilimleri Enstitüsü, Eskişehir.

Kargın, T. (1997). Farklı eğitim özgeçmişlerine sahip öğretmenlerin işitme engeline ilişkin bilgi düzeyleri ile işitme engelli çocuklar ve anne-babalarına yönelik tutumların karşılaştırılması. Yayımlanmamış doktora tezi, Ankara Üniversitesi, Sosyal Bilimler Enstitüsü, Ankara.

Kargın, T., Acarlar, F. ve Sucuoğlu, B. (2005). Öğretmen, yönetici ve anne babaların kaynaştırma uygulamalarına ilişkin görüşlerinin belirlenmesi. Özel Eğitim Dergisi, 4(2), 55-76.

Kırcaali-İftar, G. (1992). Özel eğitimde kaynaştırma. Ĕgitim ve Bilim Dergisi, 16, 45-50.

Kırcaali-İftar, G. (1998). Kaynaştırma ve destek özel eğitim hizmetleri. S. Eripek (Ed.), Özel eğitim (ss. 17-25). Eskişehir: Anadolu Üniversitesi Açık Öğretim Fakültesi Yayınları. 
König, A. (2009). Observed classroom interaction processes between pre-school teachers and children: Results of a video study during free-play time in German pre-schools. Educational and Child Psychology, 26(2), 53-65.

Küçükahmet, L. (Ed.). (2004). Sınıf yönetimi. Ankara: Nobel Yayın Dağıtım.

Mahoney, G. \& Powell, A. (1988). Modifying parent-child interaction: Enhancing the development of handicapped children. The Journal of Special Education, 22(1), 82-96.

Mahoney, G. \& Wheeden, C. A. (1999). Effects of teacher style on interactive engagement of preschool-aged children with special learning needs. Early Childhood Research Quarterly, 14(1), 51-88.

Milli Eğitim Bakanlığı (1997). 573 Sayılı Özel Eğitim Hakkında Kanun Hükmünde Kararname. Ankara: Özel Eğitim Rehberlik ve Danışma Hizmetleri Genel Müdürlüğü. Milli Eğitim Bakanlığı (2013). Okul Öncesi Ĕ̆itim Programı Etkinlik Kitabı. Ankara: MEB Yayınları.

Murray, C. \& Greenberg, M. T. (2000). Children's relationship with teachers and bonds with school an investigation of patterns and correlates in middle childhood. Journal of School Psychology, 38(5), 423-445.

Nelson, J. R. \& Roberts, M.L. (2000). Ongoing reciprocal teacher-student interactions involving disruptive behaviors in general education classrooms. Journal of Emotional and Behavioral Disorders, 8(1), 27-37.

Odom, S. L., Yoder, P. \& Hill, G. 1988. Developmental intervention for infants with handicaps: Purposes and programs. The Journal of Special Education, 22(1), 11-24.

Odluyurt, S. (2012). Okul öncesi kaynaştırma. S. Batu, A. Çolak ve S. Odluyurt (Ed.), Özel Gereksinimli Çocukların Kaynaştırılması (ss.139-171). Ankara: Vize Yayıncılık.

Odom, S. L. \& McEvoy, M. A. (1990). Mainstreaming at the preschool level: Potential barriers and tasks for the field. Topics in Early Childhood Special Education, 10(2), 4861.

Özbaba, N. (2000). Okul öncesi eğitimcilerin ve ailelerin özel eğitim muhtaç çocuklar ile normal çocukların kaynaştırılmasına karşı tutumları. Yayımlanmamış yüksek lisans tezi, Marmara Üniversitesi, Eğitim Bilimleri Enstitüsü, İstanbul.

Özen, A. (2010). Özel gereksinimli çocuklar ve oyun. İ. H. Diken (Ed.), Erken çocukluk eğitimi (ss. 435-458). Ankara: Pegem Akademi.

Pianta, R.C. (1997). Adult-child relationship processes and early schooling. Early Educationand Development, 8, 11-26. 
Rakap, S. ve Parlak-Rakap, A. (2011). Effectiveness of embedded instruction in early childhood special education: a literature review. European Early Childhood Education Research Journal, 19(1), 79-96.

Roorda, D. L.,. Koomen, H. M. Y., Spilt, J. L., Thijs, J. T. \& Oort, F. J. (2013). Interpersonal behaviors and complementarity in interactions between teachers and kindergartners with a variety of externalizing and internalizing behaviors. Journal of School Psychology, 51, $143-158$.

Rudasill, K. M. \& Rimm-Kaufman, S. E. (2009).Teacher-child relationship quality: The roles of child temperamentand teacher-child interactions. Early Childhood Research Quarterly, 24, 107-120.

Rudasill, K. M. (2011). Child temperament, teacher-child interactions and teacher-child relationships: A longitudinal investigation from first to third grade. Early Childhood Research Quarterly, 26, 147-156.

Sazak-Pınar, E. (2009). Kaynaştırma sınıfı ögretmenlerinin sosyal becerilere ilişkin beklentileri ve sosyal beceri öğretim programının öğretmen çıktıları üzerindeki etkililiğinin incelenmesi. Yayımlanmamış doktora tezi, Ankara Üniversitesi, Eğitim Bilimleri Enstitüsü, Ankara.

Sazak-Pınar, E. ve Güner-Yıldız, N. (2013). Öğretmenlerin özel gereksinimli olan ve olmayan öğrencilerin akademik ve sosyal davranışları için kullandıkları onaylama ve onaylamama davranışlarının incelenmesi. Kuram ve Uygulamada Eğitim Bilimleri, 13(1), 541-556.

Scruggs, T.E. \& Mastropieri, M.A. (1996). Teacher perceptions of mainstreaming/inclusion 1958-1995: A research synthesis. Exceptional Children, 63(1), 59-74.

State of Delaware Developmental Disabilities Council (2007). What is a Developmental Disability? http://ddc.delaware.gov/faqs.shtml. 15.08.2017 tarihinde erişildi. Şeker, A. (2000). Sınıf öğretmenlerinin iletişim becerileri ile sınıf atmosferi arasındaki ilişkinin çeşitli değişkenler açısından incelenmesi. Yayımlanmamış yüksek lisans tezi, Selçuk Üniversitesi, Sosyal Bilimler Enstitüsü, Konya.

Tekin-İftar, E. (2014). Uygulamalı davranış analizi (1. Baskı). Ankara: Vize Yayıncılık. Tekin-İftar, E. ve Kırcaali-İftar, G. (2013). Özel eğitimde yanlışsız öğretim yöntemleri. Ankara: Vize Yayıncilık. 
Thijs, J., Koomen, H., Roorda, D. \& Hagen, J. (2011). Explaining teacher-student interactions in early childhood: An interpersonal theoretical approach. Journal of Applied Developmental Psychology, 32, 34-43.

Toper-Korkmaz, Ö. (2015). Eve dayalı olarak gerçekleştirilen etkileşim temelli erken çocuklukta müdahale programının (eteçom) otizm spektrum bozukluğu tanılı çocuklar ve anneleri üzerindeki etkililiği. Yayımlanmamış doktora tezi. Anadolu Üniversitesi, Eğitim Bilimleri Enstitüsü, Eskişehir.

Töret, G., Özdemir, S. ve Özkubat, U. (2015). Ciddi düzeyde otizm spektrum bozukluğu olançocuklar ile annelerinin ebeveyn-çocuk etkileşimlerinin ebeveyn ve çocuk davranışları açısından incelenmesi. Ankara Üniversitesi Ĕgitim Bilimleri Fakültesi Dergisi, 16(1), 1-22.

Trawick-Smith, J. \& Dziurgot, T. (2010). Untangling teacher-child play interactions: do teacher education and experience influence “good-fit” responses to children’s play? Journal of Early Childhood Teacher Education, 31, 106-128.

Tseng, S. H. (2015). Children’s initiations and teachers’ responses inregular preschool classroomsin Taiwan. Infants ve Young Children, 28(3), 281-291.

Tu, T. H. \& Hsiao, W.Y. (2008). Preschool teacher-child verbal interactions in science teaching. Electronic Journal of Science Education, 12(2), 199-224.

Tüfekçioğlu, U. (2001). Okul öncesi eğitimde oyun ve önemi. U. Tüfekçioğlu (Ed.), Çocukta hareket, oyun gelişimi ve ögretimi (ss. 2-34). Eskişehir: Anadolu Üniversitesi Yayınları. Wortham, S. C. (1998). Early childhood curriculum developmental bases for learning and teaching. USA: Prentice Hall. Inc.

Yıldırım-Doğru, S. (2013). Erken çocukluk özel eğitimi. A. Cavkaytar (Ed.), Özel ĕğitim (ss. 317-340). Ankara: Vize Yayıncıl1k.

Yıldırım, A. ve Şimşek H. (2016). Sosyal bilimlerde nitel araştırma yöntemleri. Ankara: Seçkin Yayıncılık. 


\section{Summary}

\section{Statement of Problem}

Constituting the most vital point of education and the utter important process that cannot be left to chance for children with developmental disabilities, the early childhood education (Ar1, 2005); must be conducted both systematically and in a planned fashion (Avc1 and Ersoy, 2002). Early childhood education for children with developmental disabilities is given in various home, home and institution and institution based programmes while taking children's age, type of disability and family needs into consideration (Yıldırım Doğru, 2013). The most important early childhood education form that the children with developmental disabilities in institution based programmes benefits is mainstreaming.

Mainstreaming is a full or part-time education taken place in the least restrictive environment, which is in normal education environments with their normally developing peers, while providing necessary support services, for the children suffering from developmental disabilities (Kurcaali İftar, 1992). Teacher interaction behaviours possess a paramount role in the success mainstreaming classes where children with developmental disabilities live through their early education experiences. Teacher interaction behaviours are verbal and non-verbal behaviours showed by educators in education environments to support and inspire children throughout their education processes. Within field literature, interaction behaviours are contextualised as being sensitive, responsive, collimator, using reinforce and having joy (Elicker and Fortner Wood, 1995; Hamre and Pianta, 2005; Mahoney and Powell, 1988; Mahoney and Wheeden, 1999).

Teacher interaction behaviours during early childhood have a certain effect on the development of cognitive, social, emotional, lingual and communicative skills of children. While teacher interaction behaviours ease the way for children to communicate with their environments via initiatives of friendship, game participation and starting communication; they also, contribute children to become a part of society upon activities contributing their daily life skills (Kurcaali İftar, 1998). Observing the differences of teacher interaction behaviours pending on children' possession or non-possession of developmental disabilities in early childhood will result in determining teacher-child interactions and the nature of educational support and enhancing teacher awareness so that educators would build a positive attitude towards children with developmental disabilities. The aim of the present research, done according to these thoughts, is to observe teacher interaction behaviours with children in early childhoods pending on their possession or non-possession of developmental disabilities. 


\section{Method}

This is a descriptive research that utilises quantitative research pattern. As designed in a quantitative approach, in this research, a configured observation form, based on certain verbal and non-verbal behaviours, is used in data collection. In this work, the verbal and non-verbal behaviours of children with or without developmental disabilities in pre-school and pre-school classes has been evaluated through a observation form also configured in a semi-configured environment. Research has been carried out in five independent pre-schools and five pre-school classes in Ankara, connected to the Ministry of Education. A total of 14 teachers and 32 children, one child with and without developmental disability from the class of 12 preschool teachers and two children with and without developmental disability from the classroom of two teachers, participated in the study.

In order to investigate the teacher interaction behaviour depending on the possession or non-possession of developmental disabilities of children during early childhood, researchers used "Teacher Interaction Behavior Observation Form" and "Teacher and Student Information Form” specifically developed for this research. Interaction behaviours of teachers included in the “Teacher Interaction Behavior Observation Form” are; Teacher responds to the verbal or non-verbal interaction attempts by child with verbal or non-verbal behaviours, teacher offers child verbal or non-verbal stimulus, teacher presents a choice for the child, maintains/directs child attention, teacher takes a suitable tone while conversing with the child, establishes a physical interaction with the child, helps whenever the child needs, re-channels/guides child to the activity, guides child to interact with peers, approves the positive behaviour of child. During the study, observations have been made during game and desk work activities and evaluated according to the "Teacher Interaction Behavior Observation Form”. During the activities taken place in various times a video record has been taken in the classes of 14 teachers. Depending on the performance durations of the activities, video recordings varied between 15-40 minutes.

Video recordings taken in order to assess teacher interaction behaviours have been filled according to "Teacher Interaction Observation Behavior Form”. "Partial interval recording” data recording technique have been used for each video recording. Data collection form has been composed from 10 minutes and 10 seconds of divided intervals of target behaviors in the Teacher Interaction Observation Form according to the partial interval recording. The form itself has been prepared in 10 minutes and 10 seconds intervals by scoring as "teacher has interaction with the child" and "teacher has no interaction with the child”. If one or more target behaviour had been performed on every designated 10 minutes and 10 seconds of classes, the 
teacher is given the score of "teacher has interaction with the child" $(+)$, if none of the target behaviours has been performed, the teacher is given the score of "teacher has no interaction with the child” (-).

In the research, data has been analysed according to the descriptive analyse technique and findings has been presented according to the relevant frequency and ratio calculations accommodating quantitative descriptive analysis technique. Data received during the research has been analysed according to the SPSS computer programme.

\section{Results and Discussion}

The aim of this work is to observe teacher interaction behaviours where children do or don't possess developmental disabilities. The result of this research depicts that; while teachers used "offering verbal or non-verbal stimulus, perpetuates/channels child attention and taking a suitable tone while conversing with the child” behaviours more frequently, they used "offering the child with choices, guiding the child to interact with peers and approves the positive behaviour of child” less frequently. During desk and game activities it has been found out that; teachers do not depict significant differences in their general interaction behaviours whether the children do or don't possess developmental disabilities. But, when sub-levels of interaction behaviours to be considered; there is a significant difference emerged in the frequency "offering child verbal or non-verbal stimulus, establishing a physical interaction with the child, helping whenever the child needs and maintaining/directing child towards activity” behaviours. It is asserted that; teachers utilised such behaviours more frequently in their interactions with children having developmental disabilities.

This research has some limitations. First, variations of activities and time observation are two of the limitations concerning the collection of research data. It can be offered that; in further studies larger activity areas could be used and longer observation times could be spared. Difficulties, faced in gaining necessary permissions from teachers, parents and admin staff, could be counted as the second limitation. 